\title{
History of Mathematics in the Turkish Middle School Mathematics Curriculum and Textbooks
}

\section{Gülçin TAN-ŞiŞMAN ${ }^{{ }^{*}}$, Büşra KíREZ ${ }^{a}$}

\author{
${ }^{a}$ Hacettepe Üniversitesi, Eğitim Fakültesi, Ankara/TÜRKIYE
}

CrossMark

\section{Article Info}

DOI: $10.14812 /$ cuefd. 361176

Article history:

Received 04.12.2017

Revised 05.04.2018

Accepted 09.04.2018

Keywords:

History of Mathematics,

Turkish Middle School

Mathematics Curriculum,

Turkish Mathematics Textbooks.

\begin{abstract}
The purpose of this study was to analyze how the history of mathematics incorporated into Turkish middle school mathematics curriculum $\left(5^{\text {th }}-8^{\text {th }}\right.$ grades $)$ and textbooks. The data were collected through document analysis from the Turkish middle school mathematics curriculum guide $\left(5^{\text {th }}-8^{\text {th }}\right.$ grades) and six Turkish middle school mathematics textbook series approved by the National Board of Education. According to the results gathered from the math curriculum, only one reference of the history of mathematics was found in the sixth-grade learning objectives and a few suggestions acknowledging the use of the history of mathematics in the learning and teaching process. No trace of the history of mathematics found in the content and assessment aspects of the curriculum. Further, the total number of the instances of the history of mathematics found in the six Turkish middle school mathematics textbooks for $5^{\text {th }}-8^{\text {th }}$ grade is only twenty-seven. Most of the references found in the math textbooks were placed in the introduction part of the topic. Based on the findings, it is obvious that the history of mathematics was used like a rarely-found appetizer both in the curriculum and the textbooks.
\end{abstract}

\section{Ortaokul Matematik Dersi Öğretim Programı ve Matematik Ders Kitaplarında Matematik Tarihi}

\section{Makale Bilgisi}

DOI: $10.14812 /$ cuefd.361176

\section{Makale Geçmişi:}

Geliş 04.12.2017

Düzeltme 05.04.2018

Kabul 09.04.2018

Anahtar Kelimeler:

Matematik Tarihi,

Ortaokul Matematik Dersi Öğretim

Programı,

Matematik Ders Kitapları.

*Author: gulcintans@gmail.com
Öz

Bu çalışmanın amacı, matematik tarihine Türkiye'de ortaokul düzeyindeki matematik dersi öğretim programında (5-8. Sınıflar) ve ortaokul matematik ders kitaplarında nasıl yer verildiğini analiz etmektir. Araştırma verileri ortaokul matematik dersi öğretim programı kılavuzundan ve Milli Eğitim Bakanlığı tarafından onaylanmış olan ortaokul matematik dersi kitaplarından doküman incelemesi yoluyla elde edilmiştir. Ortaokul matematik dersi öğretim programının öğelerine ilișkin bulgulara göre, 6.sınıf kazanımlarında matematik tarihine ilişkin sadece bir referans ve öğrenme-öğretme durumlarında ise matematik tarihinin kullanımına yönelik bazı öneri niteliğinde ifadeler bulunmuştur. İçerik ve ölçme-değerlendirme durumlarında ise matematik tarihine ilişkin hiçbir bulguya rastlanmamıştır. Ayrıca 5-8.sınıf ortaokul matematik dersi kitaplarında matematik tarihine ilişkin toplamda yirmi yedi tane örnek tespit edilmiştir. Matematik ders kitaplarında tespit edilen örneklerin çoğu, konuların giriş kısımlarında yer almaktadır. Elde edilen bulgulara göre, matematik tarihinin hem programda hem de ders kitaplarında nadir bulunan bir çerez niteliğinde ele alındığı açıktır. 


\section{Introduction}

As a human endeavor and a rich cultural background, mathematics is one of the fundamental school subjects more than four thousand years of history. While it is widely acknowledged that mathematics is alive science involving the aspects of daily and professional life, most of the students believe that mathematics is only about numbers, theorems, symbols, and procedures. One of the reasons behind the belief that math is a mechanical subject might be due to the ways in which students experience and engage with mathematics. As McCartney (2012, p.5) argued "Mathematics is usually, and of course correctly, presented 'ready-made' to students, ... However, like any other academic subject, mathematics has a history which is rich in astonishing breakthroughs, false starts, misattributions, confusions and dead-ends." History of mathematics is defined as an immense range of study field concerning the processes of growth and advancements in mathematical knowledge through focusing on the sources of discoveries in mathematics, the accomplishments, problems, thoughts of well-known mathematicians (Burton, 2003; Eves, 1990; Katz, 1993; Otte, 2007; Yee \& Chapman, 2011).

Focusing on the integration of the history of mathematics, the ignored part of school mathematics, may foster students' cognitive and affective growth. Fried (2001) argued that history of mathematics (a) reveals humanistic aspects of mathematics; (b) makes mathematics interesting, more understandable and approachable; and (c) indicates the origin of mathematical concepts and procedures. Besides, several research studies on the integration of history of mathematics into mathematics education have indicated that history of mathematics has potential to promote more positive students attitudes (Furinghetti, 2000; Liu, 2003; Marshall, 2000; McBride \& Rollins, 1977) as well as to facilitate meaningful understanding of mathematical concepts, procedures and problems through the use of alternative examples, solution processes, strategies and methods from the history (Helfgott, 2004; Ho, 2008; Kleiner, 2001). Further, the multicultural nature of mathematics might be enhanced by the integration of history of mathematics (Ernest, 1988). According to Jankvist, (2009) "There can be no learning of mathematics without history" (p.238). The findings of many studies have not only supported to the use of history of mathematics in the learning and teaching process and also indicated many benefits for teachers and students from elementary to college level (Albayrak, 2011; Başıbüyük, 2012; Bayam, 2012; Bellomo \& Werheimer, 2010; Ersoy \& Öksüz, 2016; Fauvel, 1991; Hagerty, Smith \& Goodwin, 2007; Jankvist, 2009a; Kaye, 2008; Leng, 2006; Lim, 2011; Liu \& Niess, 2006).

Considering a range of well-known arguments in favor of integration of history of mathematics in classrooms (Fauvel, 1991; Fauvel \& Van Maanen, 2000; Jankvist, 2009), the first question might be the following: "What is the official document indicating the history of mathematics aimed to be integrated into the teaching and learning of mathematics?" The first possible answer might be "formal/intended curriculum". Posner (1995) defined formal curriculum as an official curriculum "described in formal documents" (p.12). Similarly, Porter and Smitson (2001, p.2) characterized formal curriculum as policy tools including "curriculum standards, frameworks, or guidelines that outline the curriculum teachers are expected to deliver". In this respect, formal curriculum might be considered as an officially-written document that specifies what/how students are expected to learn and what/how teachers are expected to teach and assess. The second possible answer for the question raised above might be "textbooks" since they are curriculum materials produced to support curriculum as well as instruction. According to the Mullis, Martin, Foy, and Arora's study (2012), mathematics textbooks are one of the main instructional sources of teachers in many countries. Previous research has clearly indicated that math textbooks play a central role in translating the intended curriculum into the opportunities to learn in classrooms (Arseven, 2003; Başer, 2012; Collopy, 2003; Fan, Zhu, \& Miao, 2013; Reys, Reys, Lapan, Holliday, \& Wasman, 2003; Tan-Şişman \& Akkaya, 2017; Tyson \& Woodward, 1989; Woodward \& Elliott, 1990). Valverde, Bianchi, Wolfe, Schmidt, and Houang (2002) conceptualized textbooks by using the term "potentially implemented curriculum" serving as a bridge between the intended and the implemented curriculum. In this sense, curriculum and textbooks are considered as the initial parts of mathematics education and they are one of the primary sources indicating the extent to which history of mathematics is taken into account by decision-makers and curriculum developers. 
Although the integration of history of mathematics has continued to receive a great deal of attention over the last decades, especially after the publication of Fauvel and Van Maanen's edited book (2000) "History in Mathematics Education: An ICMI Study", there has been a little effort to incorporate the historical dimension of mathematics both in mathematics curriculum and textbooks (Ho, 2008; Xenofontos \& Papadopoulos, 2015). As seen in Table 1, the contemporary studies on history of mathematics have been conducted with different participants (e.g. middle school students, math teachers, etc.), various research designs (qualitative, quantitative and mixed) as well as focused on different aspects (e.g. beliefs, attitudes, knowledge level, etc.).

Table 1.

The contemporary studies on the integration of history of mathematics

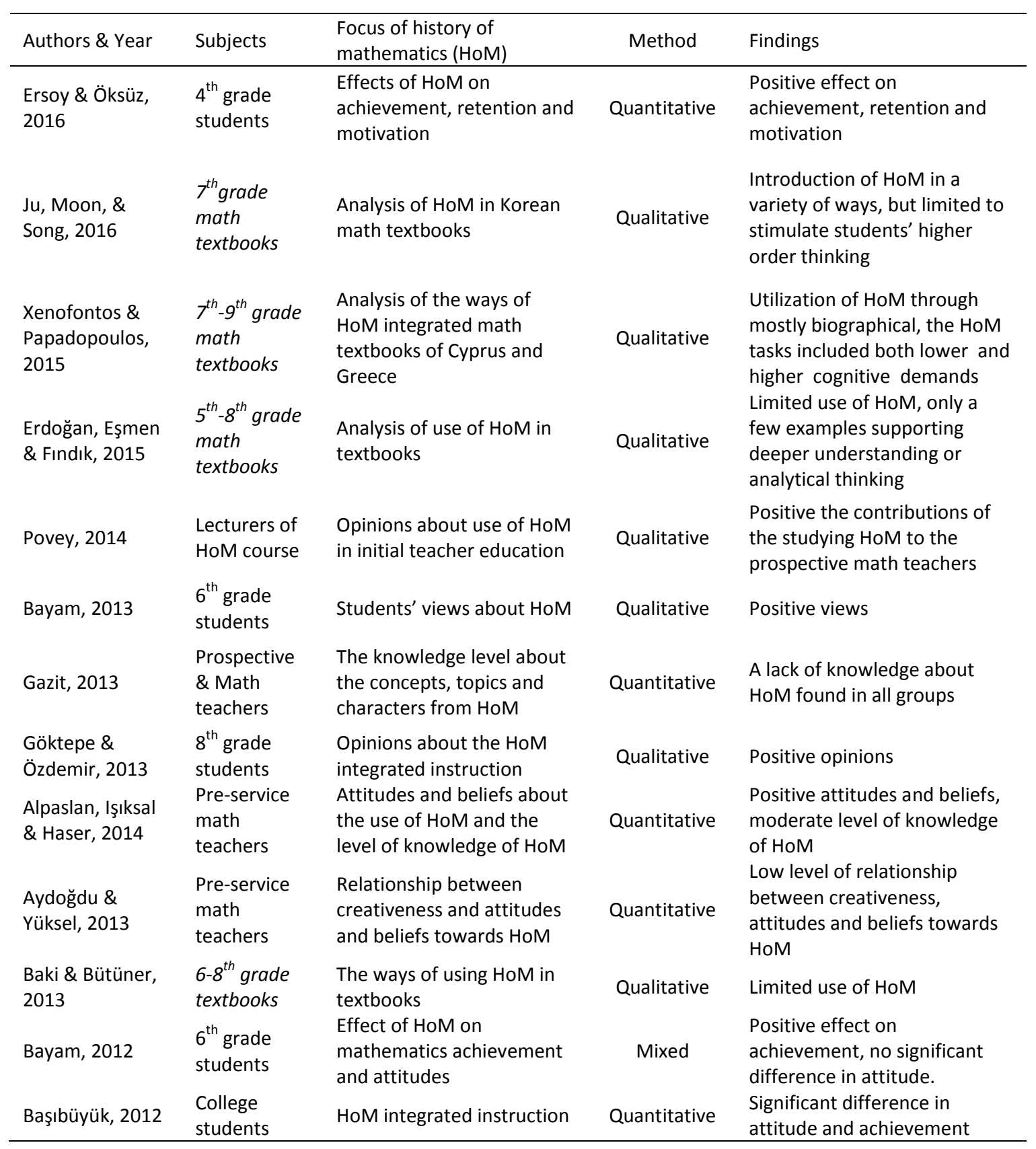


Table 1.

The current studies on the integration of history of mathematics (cont'd)

\begin{tabular}{|c|c|c|c|c|}
\hline Authors \& Year & Subjects & $\begin{array}{l}\text { Focus of history of } \\
\text { mathematics (HoM) }\end{array}$ & Method & Findings \\
\hline $\begin{array}{l}\text { Özdemir, } \\
\text { Göktepe \& } \\
\text { Kepçeoğlu, } 2012\end{array}$ & $\begin{array}{l}11^{\text {th }} \text { grade } \\
\text { students }\end{array}$ & $\begin{array}{l}\text { Use of HoM in geometric } \\
\text { proofing }\end{array}$ & Qualitative & $\begin{array}{l}\text { Increase in geometric proof } \\
\text { skills }\end{array}$ \\
\hline $\begin{array}{l}\text { Panasuk \& } \\
\text { Horton, } 2012\end{array}$ & Math teachers & $\begin{array}{l}\text { Perceptions and the factors } \\
\text { related to the integration of } \\
\text { the HoM }\end{array}$ & Quantitative & $\begin{array}{l}\text { A lack of knowledge and } \\
\text { confidence in HoM, time, } \\
\text { testing, resources found as } \\
\text { factors }\end{array}$ \\
\hline Clark, 2012 & $\begin{array}{l}\text { Pre-service } \\
\text { math teachers }\end{array}$ & $\begin{array}{l}\text { Impact of the study of the } \\
\text { HoM on mathematical } \\
\text { knowledge for teaching }\end{array}$ & Qualitative & $\begin{array}{l}\text { Positive impacts on the pre- } \\
\text { service teachers' pedagogical } \\
\text { knowledge }\end{array}$ \\
\hline Yenilmez, 2011 & $\begin{array}{l}\text { Pre-service } \\
\text { math teachers }\end{array}$ & $\begin{array}{l}\text { Opinions about the HoM } \\
\text { course }\end{array}$ & Quantitative & $\begin{array}{l}\text { Positive opinions about the } \\
\text { course }\end{array}$ \\
\hline Burns, 2010 & $\begin{array}{l}\text { Pre-service } \\
\text { math teachers }\end{array}$ & $\begin{array}{l}\text { Views' about the use of HoM } \\
\text { and the role of HoM }\end{array}$ & Mixed & $\begin{array}{l}\text { Positive views and changes in } \\
\text { beliefs about incorporation of } \\
\text { HoM in math lessons }\end{array}$ \\
\hline Gürsoy, 2010 & $\begin{array}{l}\text { Pre-service } \\
\text { math teachers }\end{array}$ & $\begin{array}{l}\text { Attitudes and beliefs about } \\
\text { the use of HoM in teaching of } \\
\text { math }\end{array}$ & Mixed & Positive attitudes and beliefs \\
\hline $\begin{array}{l}\text { Huntley \& Flores, } \\
2010\end{array}$ & $\begin{array}{l}\text { Pre-service } \\
\text { math teachers }\end{array}$ & $\begin{array}{l}\text { Views' about the HoM course } \\
\text { to develop mat knowledge for } \\
\text { teaching }\end{array}$ & Qualitative & $\begin{array}{l}\text { Positive opinions and } \\
\text { contributions }\end{array}$ \\
\hline Jankvist, 2010 & $\begin{array}{l}\text { Secondary } \\
\text { school } \\
\text { students }\end{array}$ & $\begin{array}{l}\text { Reflections about the meta- } \\
\text { issues of mathematics and its } \\
\text { history }\end{array}$ & Quantitative & $\begin{array}{l}\text { The students were capable of } \\
\text { discussing and reflecting upon } \\
\text { meta-issues of mathematics } \\
\text { and its history. }\end{array}$ \\
\hline $\begin{array}{l}\text { Thomaidis \& } \\
\text { Tzanakis, } 2009\end{array}$ & $\begin{array}{l}7^{\text {th }}-9^{\text {th }} \text { grade } \\
\text { math textbooks }\end{array}$ & $\begin{array}{l}\text { Analysis of use of HoM in } \\
\text { Greek high school math } \\
\text { textbooks }\end{array}$ & Qualitative & $\begin{array}{l}\text { Numerous historical examples } \\
\text { of math, but including errors, } \\
\text { obscurities, or } \\
\text { omissions }\end{array}$ \\
\hline $\begin{array}{l}\text { Baki \& Güven, } \\
2009\end{array}$ & $\begin{array}{l}\text { Pre-service } \\
\text { math teachers }\end{array}$ & $\begin{array}{l}\text { Experiences related to use of } \\
\text { Dynamic Geometry Program } \\
\text { when solving the quadratic } \\
\text { equation with Khayyam } \\
\text { Method }\end{array}$ & Qualitative & $\begin{array}{l}\text { Positive feelings, recognition } \\
\text { of the Khayyam's math, } \\
\text { making relations between } \\
\text { modern math and Khayyam's } \\
\text { era }\end{array}$ \\
\hline Smestad, 2008 & Math teachers & $\begin{array}{l}\text { Conceptions' about HoM in } \\
\text { the curriculum }\end{array}$ & Qualitative & $\begin{array}{l}\text { Different conceptions about } \\
\text { HoM, different use of HoM } \\
\text { with different degrees }\end{array}$ \\
\hline Tözluyurt, 2008 & $\begin{array}{l}\text { Senior high } \\
\text { school } \\
\text { students }\end{array}$ & $\begin{array}{l}\text { Opinions about the HoM } \\
\text { integrated instruction }\end{array}$ & Qualitative & Positive opinions \\
\hline İdikut, 2007 & $\begin{array}{l}7^{\text {th }} \text { grade } \\
\text { students }\end{array}$ & $\begin{array}{l}\text { Effects of HoM on } \\
\text { achievement and attitudes }\end{array}$ & Quantitative & $\begin{array}{l}\text { Positive effect on } \\
\text { achievement, no significant } \\
\text { difference in attitude }\end{array}$ \\
\hline Smestad, 2000 & $\begin{array}{l}\text { Norwegian } \\
\text { math textbooks }\end{array}$ & $\begin{array}{l}\text { Analysis of HoM in Norwegian } \\
\text { textbooks }\end{array}$ & Qualitative & $\begin{array}{l}\text { A very limited use of HoM } \\
\text { some of them inaccurate, } \\
\text { based on myths. }\end{array}$ \\
\hline
\end{tabular}

However, as seen in the Table 1, a few studies were focused on the use of historical foundations of mathematical thinking in the mathematics textbooks (Baki \& Bütüner, 2013; Erdoğan, Eşmen \& Fındık, 2015; Smestad, 2000; Thomaidis \& Tzanakis, 2009; Xenofontos \& Papadopoulos, 2015). Besides, the 
lines of several reports have also revealed a little effort to incorporate the historical dimension of mathematics both in elementary and middle school mathematics curriculum and textbooks ( $\mathrm{Ho}, 2008$; Radford, Furingetti \& Katz, 2007; Xenofontos \& Papadopoulos, 2015). In the light of these issues, the purpose of the study was to analyze the Turkish middle school mathematics curriculum and mathematics textbooks in terms of how the history of mathematics was addressed. Indeed, the present study essentially sought to answer the following questions:

1. How is the history of mathematics addressed in the main components of Turkish middle school mathematics curriculum, namely, learning objectives, content, delivery, and assessment process?

2. How the history of mathematics is addressed in the Turkish middle school mathematics textbooks?

It is believed that the results of this study will be valuable for curriculum developers, scholars, and teachers who would like to search an example of the mathematics curriculum and textbooks within the historical perspective. It is also believed that the results may contribute to the ongoing research by giving an example from the Turkish educational context. Although the focus of the study was not on the implementation of the curriculum as well as the use of the textbooks in classrooms, the results may also shed light on the relationship between the intentions about the use of the history of mathematics as stated in the official curriculum and the indications of the potential learning opportunities related to the history of mathematics as included in the textbooks, in essence, as in the "potentially implemented curriculum" (to use Valverde, et al.'s words [2002, p.13]).

Before moving to the next parts, it is believed that the general information about the national setting of mathematics education in Turkey, where the study stems from, might be useful starting point for a better understanding. Turkish education system has a highly centralized governance structure and the Ministry of National Education (MONE) is the main body for planning, programming, executing, monitoring and controlling all educational services including curriculum development and approval of textbooks. In 2005, the striking curricular change was made in order to develop a more learner-centered curriculum and a more constructivist way of learning. In 2012, with the announcement of the new law, the length of compulsory education was increased from 8 to 12 years and redefined the system into 3 levels (12-years compulsory education covering 4-years elementary, 4-years middle and 4-years high school). As a result of this structural reform, the MONE had to make the second important curricular revision. The revised Turkish middle school mathematics curriculum $\left(5^{\text {th }}-8^{\text {th }}\right.$ grade) was put into implementation during the 2013-2014 academic year. The goal of the revised mathematics curriculum is stated as to provide a learning environment in which students will gain mathematical knowledge and skills required by the $21^{\text {st }}$ century (MONE, 2013). With regard to the content, there are five main learning strands, namely, numbers and operations; geometry and measurement; algebra; data analysis; and probability. In addition, the development of students' problem solving skills, mathematical processing skills (e.g. reasoning, communication, etc.), affective dimensions (attitude, self-confidence, self-regulation, etc.), and psychomotor skills are highly emphasized issues in the curriculum.

\section{Method}

This study was designed to analyze how the history of mathematics occupied in the Turkish middle school mathematics curriculum and math textbooks. For this purpose, data were collected through document analysis. The first main data source of the study was the Turkish middle school mathematics curriculum $\left(5^{\text {th }}-8^{\text {th }}\right.$ grades), namely the official curriculum document. The second main data sources were the Turkish middle school mathematics textbooks approved by MONE during the 2015-2016 academic year. There are totally six approved textbooks and all of them were included in the document analysis. All of the data sources are available on the MONE's official website. The detailed information about the textbooks is provided in Table 2 . 
Table 2.

The Turkish middle school mathematics textbooks analyzed in the study

\begin{tabular}{lll}
\hline Grade & Publisher & Total number of pages \\
\hline $5^{\text {th }}$ grade & MEB & 588 (2 volume set) \\
$6^{\text {th }}$ grade & Özgün & 264 \\
$7^{\text {th }}$ grade & Tutku Yayıncılık & 264 \\
$8^{\text {th }}$ grade & MEB & 354 \\
& Sevgi & 263 \\
Total & 6 math textbooks & 262 \\
\hline
\end{tabular}

Before the data analysis process, two frameworks were developed by the researchers. The first framework, as given in the Table 3, was developed to analyze the official mathematics curriculum in terms of the main components, namely, learning objectives, content, delivery, and assessment. More specifically, the attention is here on where (objectives, content, delivery, and assessment) and how (compulsory or suggested expressions) the history of mathematics incorporated in the curriculum.

Table 3.

The framework for the curriculum analysis

\begin{tabular}{ll}
\hline Where is HoM incorporated in the curriculum? & $\begin{array}{l}\text { The components of curriculum } \\
\text { Learning Objectives } \\
\text { Content/Strands } \\
\text { Teaching and learning process } \\
\text { Assessment process }\end{array}$ \\
\hline How is the HoM incorporated in the curriculum? & $\begin{array}{l}\text { The ways of expression } \\
\text { Compulsory (requirement, rule, etc.) } \\
\text { Suggested (recommendations, advice etc.) }\end{array}$ \\
\hline
\end{tabular}

The second framework, as given in the Table 4, was developed for the analysis of the math textbooks. It has two parts as the place of utilization and the way of expression. The former is focused on where the references to the history of mathematics used in the textbooks (e.g. introduction activities, explanation of the topic to be learned, closure activities, or off-topic information). The latter part, the ways of expression, is based on the Xenofontos and Papadopoulos's (2015) framework. It has four categories: (1) simple historical/biographical references; (2) solution/proof of a method including historical pieces; (3) mathematical tasks of purely cognitive elements that require a numerical solution, explanation or proof and (4) discussion/projects relating the history of mathematics with life outside mathematics. According to Xenofontos and Papadopoulos (2015), while the references clustered under the first and second categories just present encyclopedic pieces of information without posing any question to students, the references under the third and fourth categories present historical dimension of mathematics through tasks, discussions and/or projects that asked students to produce solutions or answers.

Table 4.

The framework for the textbook analysis

\begin{tabular}{ll}
\hline \multirow{2}{*}{ Where is HoM incorporated in the textbook? } & The place of utilization \\
Introduction activities (e.g. gaining attention) & Presenting topic to be learned \\
Closure activities (e.g. retention and transfer) \\
Off-topic information (i.e. not related to topic)
\end{tabular}


Table 4.

The framework for the textbook analysis (cont'd)

The ways of expression

Simple historical /biographical references

How is the HoM incorporated in the Solution/proof of a method/formula textbook?

Discussion/project tasks

In order to find out all relevant data (i.e. the references to the history of mathematics), the official curriculum and the textbooks in each grade level were carefully examined line by line according to the frameworks. During the analysis process, the researchers coded the data independently and then both sets of data were compared to establish consistency in the assignment of codes to the same category.

\section{Results}

The results gathered from the analysis of the Turkish middle school mathematics curriculum and six Turkish middle school mathematics textbooks were presented in line with two main research questions.

\section{The History of Mathematics in the Turkish Middle School Mathematics Curriculum}

The major focus of the content analysis here was to identify all instances of the history of mathematics in the Turkish Middle School Mathematics Curriculum (TMMC). Hence, learning objectives, content, delivery, and assessment aspects of the curriculum were analyzed according to the framework. The findings gathered from the content analysis are summarized in Table 5.

Table 5.

The instances of the HoM in the curriculum

\begin{tabular}{llc}
\hline $\begin{array}{l}\text { The components of } \\
\text { curriculum }\end{array}$ & Instances of the HoM found in the curriculum & The ways of expression \\
\hline $\begin{array}{l}\text { Learning Objectives } \\
\text { Content/Strands }\end{array}$ & $\begin{array}{l}\text { 1 objective }\left(6^{\text {th }} \text { grade) }\right. \\
\text { No instances found }\end{array}$ & Compulsory \\
Learning and teaching & $\begin{array}{l}\text { The use of famous mathematicians' } \\
\text { biographies, and their contributions to the } \\
\text { process }\end{array}$ & field \\
Assessment process & No instances found & Suggested \\
\hline
\end{tabular}

Considering the learning objectives from $5^{\text {th }}$ to $8^{\text {th }}$ grades, the following sixth-grade objective (see Figure 1) was the only one instance of the history of mathematics: "determine prime numbers and their properties". The explanation of this learning objective required for "using the Sieve of Eratosthenes to find all primes up to 100 " (TMMC, $6^{\text {th }}$ grade, p. 13). Based on the explanation statement, it can be said that the way of expression is compulsory. In other words, use of the Sieve of Eratosthenes is the main requirement for achieving this learning objective.

6.1.2.3. Asal sayıları özellikleriyle belirler.

- Eratosthenes (Eratosten) Kalburu yardımıyla 100'e kadar olan asal sayılar bulunur.

Figure 1. The objective and its explanation requiring the use of the Sieve of Eratosthenes (TMMC, $6^{\text {th }}$ grade, p. 13) 
With regard to the content, among five main learning strands (i.e. numbers and operations; geometry and measurement; algebra; data analysis; and probability), no trace of the history of mathematics was found. As seen in Table 5, the history of mathematics was also reflected in the learning and teaching process. In the curriculum guide, under the title of "The Use of Information related to the Development of Mathematics" (see Figure 2), it was acknowledged that providing information about famous mathematicians' biographies, and their contributions to the field might affect students' attitudes towards mathematics positively. It is also stated that mathematics instruction should place emphasis on the contributions of Atatürk, the founder of the Turkish Republic. For instance, he is the author of the first geometry book written in Turkish as well as introduced the standard units of measurement. Since these explanations about the integration of history of mathematics with learning and teaching of mathematics are given in the form of suggestions, the way of expression of learning and teaching process is not compulsory activities. Like the content aspect of the curriculum, no trace of the history of mathematics was found in the assessment part of TMMC.

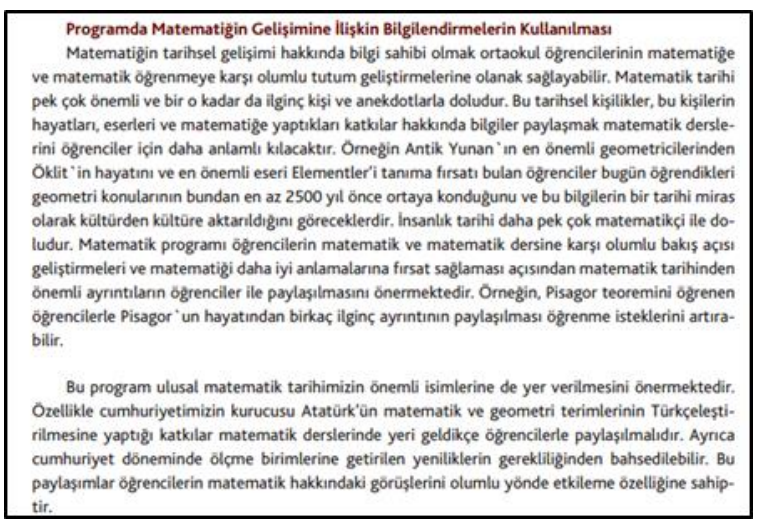

Figure 2. The extract from the Use of Information related to the Development of Mathematics (TMMC, 2013 p. VIII)

\section{The History of Mathematics in the Turkish Middle School Mathematics Textbooks}

The aim of the content analysis here was to identify all instances of the history of mathematics in the six Turkish middle school mathematics textbooks. Totally 1995 pages of the six middle school mathematics textbooks were analyzed by line by line. The total number of the HoM-related pages for all grades and all textbooks was found about thirty-five pages. Further, the total instances of the HoM found in the six middle school mathematics textbooks was only twenty-seven. The results obtained from the textbook analysis are summarized in Table 6.

Table 6.

The number of the instances of HoM in the textbooks

\begin{tabular}{lcccc}
\hline The place of utilization & $\begin{array}{l}\text { Simple historical } \\
\text { / biographical } \\
\text { references }\end{array}$ & $\begin{array}{l}\text { Solution /proof of a } \\
\text { method/ formula }\end{array}$ & $\begin{array}{l}\text { Mathematical } \\
\text { tasks }\end{array}$ & $\begin{array}{l}\text { Discussion/ } \\
\text { projects }\end{array}$ \\
\hline Introduction activities & 9 & - & 3 & 2 \\
Presenting topic to be learned & - & 3 & - & - \\
Closure activities & 6 & - & - & - \\
Off-topic extra information & 3 & - & 4 & - \\
Total & 18 & 3 & 2 & 2 \\
\hline
\end{tabular}


Considering the grade levels, the history of mathematics was mostly taken into consideration in the eighth grade, totally 12 references were found in two different textbooks. Surprisingly, as given in Table 7 , no trace of the history of mathematics was found in the seventh-grade textbook. By sixth grade, 8 references and by fifth grade 7 references were determined.

Table 7.

The number of the instances of HoM by grades

\begin{tabular}{ccccc}
\hline & & \multicolumn{2}{c}{ The place of utilization } & \\
Grades & Introduction & Presenting topic & Closure & Off-topic information \\
\hline $5^{\text {th }}$ & - & - & 7 & - \\
$6^{\text {th }}$ & 4 & 1 & - & - \\
$7^{\text {th }}$ & - & 2 & - & - \\
$8^{\text {th }}$ & 10 & 3 & 7 & 3 \\
Total & 14 & & - & - \\
\hline
\end{tabular}

According to the findings, the references related to the HoM were mostly placed in the introduction part of the topic. Figure 3 and 4 are given as examples of the use of the HoM at beginning of the mathematical topics.

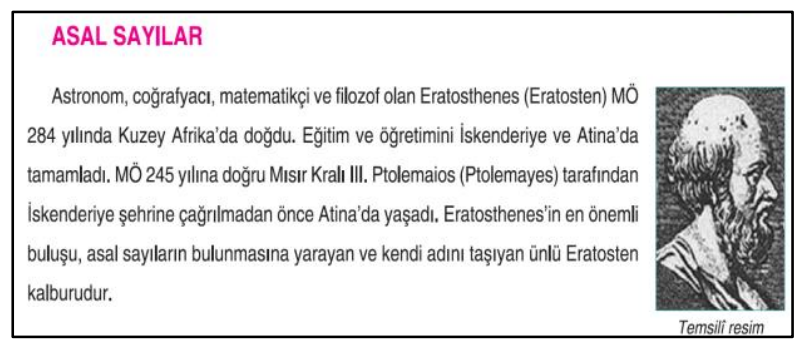

Figure 3. A short biography of Eratosthenes (Dikey, $6^{\text {th }}$ grade, p. 39)

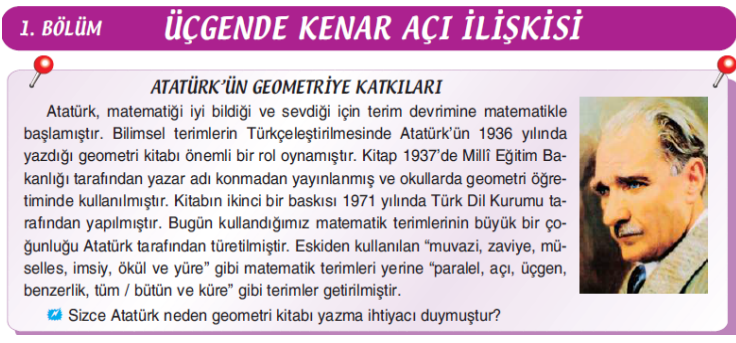

Figure 4. A short information about Atatürk and his contributions to geometry (Sevgi, $8^{\text {th }}$ grade, p. 82)

Apart from one reference from the sixth-grade and two references from eighth-grade textbooks, there was no evidence indicating the history of mathematics used while presenting the topic, concept, skill, or formula to be learned in the textbook series. Figure 5 indicates that the Sieve of Eratosthenes was used while presenting the topic of prime numbers that was also explicitly stated in the curriculum. In Figure 6, a short description about the Pascal triangle and its construction were given. 


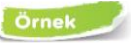

Eratosten kalburu yardimıyla 100'e kadar olan asal sayiları bulalım.

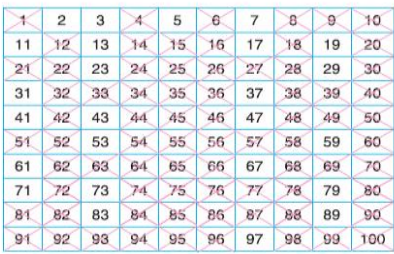

$\begin{array}{lllllllllll}81 & 82 & 83 & 84 & 85 & 85 & 87 & 88 & 89 & 90 \\ 81 & 92 & 03 & 94 & 05 & 06 & 97 & 98 & 99 & 100 & \end{array}$

Tabloda 1 asal sayı olmadığı için $\mathrm{x}$ işareti konulmuştur. 2 asal bir sayı olduğu için $\mathrm{x}$ işare

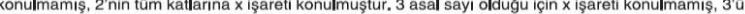
tüm kattlarına x işareti konulmuștur. Aynı ișlemi 3 'ten büyük olan x işareti konulmamış doğal sayıllar için de tekrarladığımızda tabloda sadece 100 'e kadar olan asal sayiları belirtemiş oluruz.

100 'e kadar olan asal saylar; $2,3,5,7,11,13,17,19,23,29,31,37,41,43,47,53,59,61,67,71$, $73,79,83,89$ ve 97 'dir.

Figure 5. The Sieve of Eratosthenes

(Dikey, $6^{\text {th }}$ grade, p. 41)

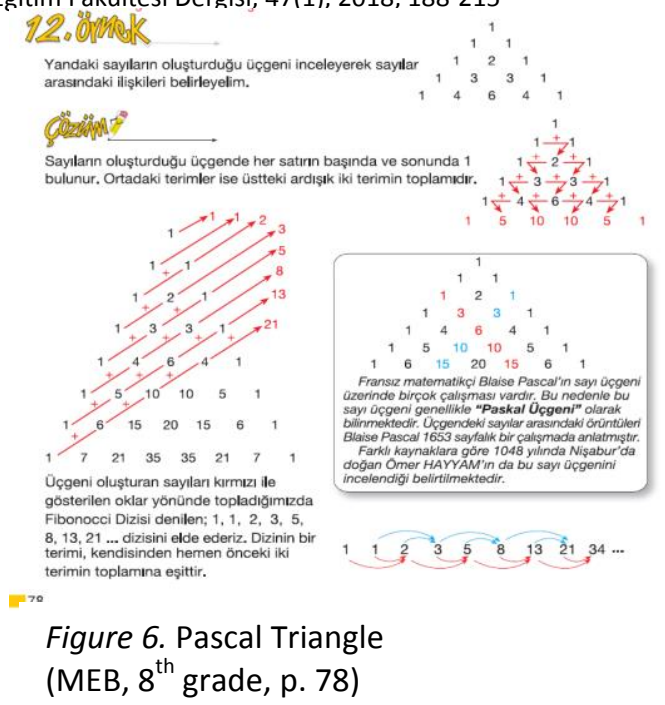

Besides, only the fifth-grade textbooks included in the references related to the HoM at the end of the topic. Figure 7 provides example of the HoM placed in the closure part that was related to Wiliam Playfair and his invention of the bar chart given at the end of the data analysis and interpretation topic. Another example as given in the Figure 8 provides brief information about the first use of parenthesis in mathematics by Christopher Clavius in 1608 and by Albert Girard in 1629.

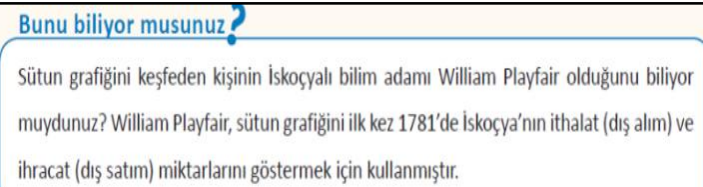

Figure 7. The Wiliam Playfair's invention of bar chart

(MEB, $5^{\text {th }}$ grade, p. 127)

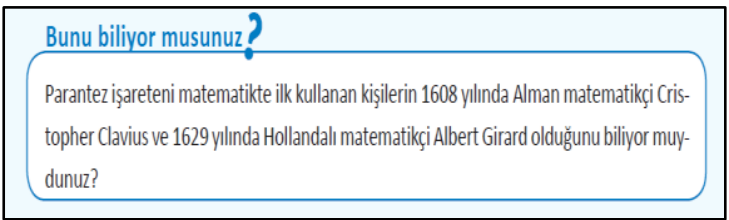

Figure 8. The first use of parenthesis in mathematics (MEB, $5^{\text {th }}$ grade, p. 61)

IMoreover, the historıcal dımensıon of mathematics were also used as off-topic extra information (i.e. not related to topic or learning objective). According to results, only 3 references were found in the sixth-grade textbook. Figure 9 indicates the use of the HoM as an off-topic information about Cahit Arf, a world-famous Turkish mathematician, in the data analysis topic.

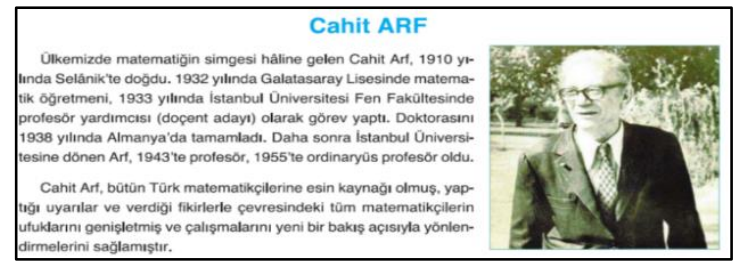

Figure 9. Cahit Arf, a world-famous Turkish mathematician (Dikey, $6^{\text {th }}$ grade, p. 151)

The findings concerning how the history of mathematics is integrated in the textbooks indicated that the history of mathematics was expressed mostly in the way of historical or biographical references. As seen in Table 8, out of 27 references, 18 of them were expressed in the form of either simple historical or biographical information. 
Table 8.

The number of the HoM references according to the ways of expression by grades

\begin{tabular}{ccc|ccc}
\hline Grades & \multicolumn{5}{c}{ The ways of expression } \\
& $\begin{array}{c}\text { No question(s) for student(s) } \\
\text { Simple historical/ } \\
\text { biographical references }\end{array}$ & $\begin{array}{c}\text { Solution /proof of a } \\
\text { method/ formula }\end{array}$ & $\begin{array}{c}\text { Mathematical } \\
\text { tasks }\end{array}$ & $\begin{array}{c}\text { Discussion/ } \\
\text { projects }\end{array}$ & Total \\
\hline $5^{\text {th }}$ & 6 & - & 1 & - & 7 \\
$6^{\text {th }}$ & 5 & 1 & 1 & 1 & 8 \\
$7^{\text {th }}$ & - & - & - & - & - \\
$8^{\text {th }}$ & 7 & 2 & 2 & 1 & 12 \\
Total & 18 & 3 & 4 & 2 & 27 \\
\hline
\end{tabular}

The examples of the references expressed in the form of simple historical or biographical information are provided in Figure 10 and 11.

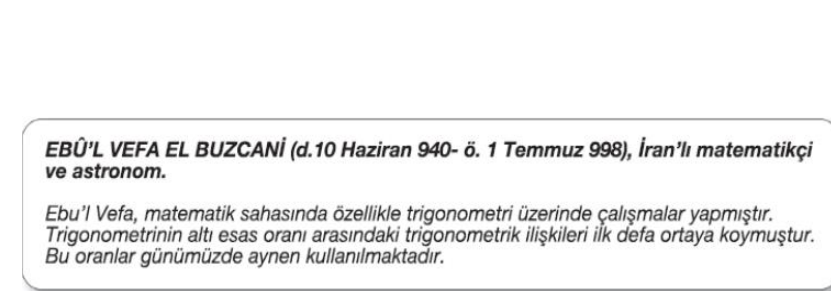

Figure 10. Abu al-Wafa' Buzjani, a Persian

mathematician and astronomer

(MEB, $8^{\text {th }}$ grade, p. 145)

\section{Ali KUŞçU}

Türk-sslam dünyasıınn büyük astronomi ve kelam âlimi olan Ali Kuş̧u, XV. yüzyl bașlarnnda Semerkant'ta doğdu. Ali Kuş̧ưnun babası Muhammed, ûnlú Tưrk sultanı ve astronomu Uluğ Bey"in kuş̧̧usu olduğu için ailesi "Kuş̧̧u" lakabryla meşhur oldu. Küçük yaştan itibaren matematiğe ve astronomiye ilgi duyan Ali Kuş̧̧, devrin en büyük âlimler olan Bursalı Kadızâde Rumî, Gıyáseddin Cemșid ve Muinuddin Kåșî́den matematik ve astronomi dersi aldı. Fatih Sultan Mehmet Ali Kuş̧̧u'yu istanbul'a davet etti. Kuş̧u padişahn tekkitini kahul att

Figure 11. Ali Kuşçu, a Turkish mathematician and astronomer (Dikey, $6^{\text {th }}$ grade, p. 127)

According to the results, a few number of references to the history of a mathematical method or formula containing a solution or proof without posing any question to student(s) were included in the mathematics textbooks. Figure 5 (The Sieve of Eratosthenes) and Figure 6 (Pascal's Triangle) exemplify how the historical references to a method and its solution process used in the textbooks. Moreover, the findings clearly indicated that the references asking students to interact with the history of mathematics were rarely included in the textbooks. Only four references related to mathematical tasks of purely cognitive elements requiring a numerical solution, explanation or proof and two references related to discussion/project tasks connecting the history of mathematics with life outside mathematics were found. Examples of these references are shown in Figures 12 and 13 respectively. Figure 12 illustrates an example of mathematical task that provides short biographical information about Pythagoras and then, asks students to explain the following question: "The Pythagorean theorem was used in the given triangle. Based on the provided information, please explain the Pythagorean theorem". In Figure 13, an example of discussion/project tasks, a short historical information about the Ancient Egyptian Number System and the table indicating what the Egyptian hieroglyphics (symbols) represent in our decimal system as well as their descriptions are provided. Afterward, students are invited to discuss the difficulties to perform calculations (addition, subtraction, multiplication, and division) by using Egyptian hieroglyphics. In order to complete this task, students need to collect information about how Egyptians carry out calculations. 


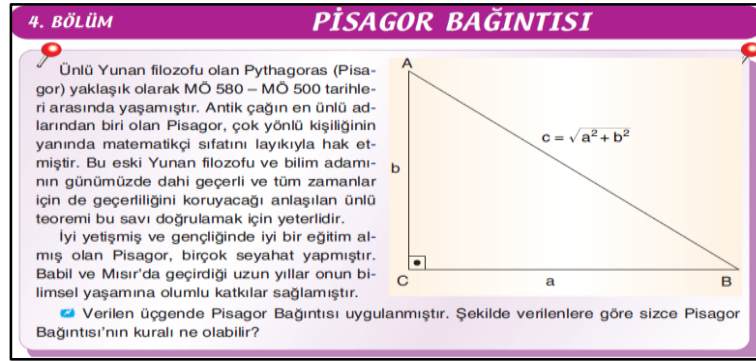

Figure 12. The Pythagorean Theorem, (Sevgi, $8^{\text {th }}$ grade, p. 110)

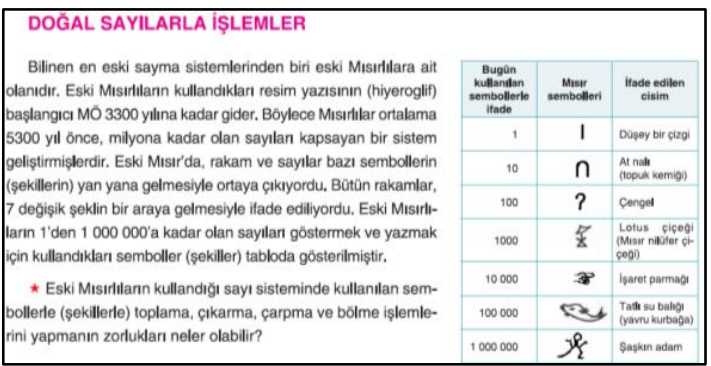

Figure 13. The Egyptian hieroglyphics, (Dikey, $6^{\text {th }}$ grade, p. 15)

\section{Discussion \& Conclusion}

In the present study, the findings clearly indicated that both the curriculum and the textbooks are attentive to the inclusion of historical aspect of mathematics. Considering the learning objectives of the TMMC, the official curriculum, there is only one objective addressed the history of mathematics explicitly. In the learning and teaching aspect of the TMMC, the important role of the history of mathematics is clearly acknowledged under the title of "The Use of Information related to the Development of Mathematics". Nonetheless, no trace of the history of mathematics was found in the content and the assessment components of the TMMC. Based on this result, it is obvious that although the role of HoM in mathematics education is taken into consideration, its integration could not be fully reflected in the components of the TMMC. In this respect, the results of the present study call for a mathematics curriculum in which all aspects from learning objectives to assessment are well-balanced in terms of historical dimensions of mathematics so that students are provided with learning opportunities to meaningfully engage with mathematics as well as extend beyond rote application of procedures. As Lingard (2000) stated "Inclusion of some history of mathematics in the school curriculum increases student motivation and achievement by humanizing the subject, emphasizing on the continuous development of math and foster an appreciation of the multicultural inheritance and culturally dependent nature of the subject" (p.16). In a similar vein, Bidwell (1993) used "island" metaphor for the mathematics instruction without its history where students perceive mathematics as "closed, dead, emotionless and all discovered" (p. 461) subject. However, the integration of the history of mathematics clearly help us to "rescue students from the island of mathematics and relocate them on the mainland of life that contains mathematics that is open, alive, full of emotion, and always interesting" (Bidwell, 1993, p. 461). Towards this aim, the history of mathematics might be connected with all main dimensions of math curriculum and become more visible and attractive for teachers and textbook writers.

Furthermore, the findings emerged from the analysis of the six Turkish middle school mathematics textbooks (for $5^{\text {th }}-8^{\text {th }}$ grades) indicated that the total page number of six textbook is 1995 and a middle school student will meet about 35 pages of history of mathematics during his/her four-year middle school process. In this respect, the inclusion of the historical dimensions of mathematics in the textbooks, namely the potentially implemented curriculum, is very limited. Smestad (2000) made a similar point with respect to the Norwegian math textbooks and found that a student will meet about 36 pages of history of mathematics in his/her ten-year schooling process. Another indicator of limited use of HoM in the textbooks is the total number of the HoM-related instances that was found only twentyseven. Considering the grade levels, no trace of the history of mathematics was found in the seventhgrade textbook. It might be interpreted that although fifth and sixth graders have little chance to see the need or rationale behind development of a mathematical concept/theorem/rule through historical perspective of math, in seventh grade, there is no chance offered for students to continue seeing mathematics as an organic whole. 
Besides, more than half of the HoM-related references in the textbooks were presented in the form of encyclopedic pieces of information. Similar results were demonstrated in previous research as well. Xenofontos and Papadopoulos's (2015) study, for instance, made a similar point with respect to the use of the history of mathematics in the Cypriot and Greek mathematics textbooks. According to Baki and Bütüner's (2013) study, the history of mathematics was mostly expressed through the short life stories and pictures of mathematicians in elementary school mathematics textbooks. In this respect, the findings of the current study clearly indicated that the references that ask students to interact with the history of mathematics were rarely included in the textbooks. One of the possible reasons behind the perfunctory attention given to the history of mathematics in the textbooks might be due to the curriculum itself. Especially such countries as Turkey, having a highly centralized educational system, a national curriculum is usually embodied in nation-wide unified textbooks. Thus, the extent to which the historical aspect of mathematics is occupied in the curriculum directly affects the scope of the historical elements in mathematics textbooks. To sum up, the findings of the present study indicated that although the TMMC and the middle school math textbooks value the history of mathematics, there are rather shallow and superficial mentions of the history of mathematics in terms of quantity and quality. 


\section{Türkçe Sürümü}

\section{Giriş}

İnsanoğlunun çabasıyla harmanlanmış zengin kültürel bir birikim olarak matematik, yaklaşık dört bin yıldan beri, en temel dersler arasında okul programlarında yer almaktadır. Matematik, günlük ve mesleki yaşamla iç içe, sürekli gelişen canlı bir bilim dalı olmasına rağmen, çoğu öğrenci matematiğin donuk, mekanik, soyut, sadece sayılar, teoremler, semboller ve prosedürlerle ilgili olduğuna inanmaktadır. Matematiğin mekanik bir yapıda olduğu inancının ardındaki nedenlerden biri, öğrencilerin matematik ile nasıl ve ne düzeyde bir deneyim ve etkileşim yaşadığıdır. McCartney'in (2012) belirttiği gibi "Matematik öğrencilere genellikle ve elbette doğru olarak " hazır" bir şekilde sunuluyor ... Ancak, diğer disiplinlerde de olduğu gibi, matematiğin yanlış başlangıçlar, yanlış anlaşılmalar, karışıklıklar ve çıkmazlarla dolu şaşırtıcı ve çığır açan bir tarihi vardır" (s.5). Matematiğin tarihi, matematikteki keşiflerin kaynakları, başarılar/başarısızlıklar, sorunlar, ünlü matematikçilerin düşünceleri ve deneyimlerine odaklanarak, matematik bilgisinin gelişim ve ilerleme süreçleri ile ilgili çok geniş bir çalışma alanı olarak tanımlanmaktadır (Burton, 2003; Eves, 1990; Katz, 1993; Otte, 2007; Yee ve Chapman, 2011).

Genellikle okul matematiğinde göz ardı edilen kısım olan matematik tarihi, öğrenme-öğretme süreciyle bütünleştirildiğinde, öğrencilerin hem bilişsel hem de duyuşsal gelişimini destekleyici bir role sahiptir. Fried (2001) matematik tarihinin (a) matematiğin insani yönlerini vurguladığını; (b) matematiği ilginç, daha anlaşılır ve ulaşılabilir kıldığını ve (c) matematiksel kavram ve işlemlerin geçmişini ortaya koyduğunu belirtmektedir. Ayrıca, matematik tarihinin matematik eğitimiyle bütünleştirilmesiyle ilgili birçok araştırma, öğrenme-öğretme sürecinde matematik tarihinin kullanımının, öğrencilerin matematiğe yönelik tutumlarını olumlu yönde gelişmesine yardımcı olduğunu göstermiştir (Furinghetti, 2000; Liu, 2003; Marshall, 2000; McBride ve Rollins, 1977). Ayrıca, matematiğin çok kültürlü doğası, matematik tarihinin öğrenme-öğretme sürecine harmanlanmasıyla artırılabilir (Ernest, 1988). Jankvist'e (2009) göre, "Tarih olmadan, matematik öğrenilemez" (s.238). Alan yazındaki birçok araştırmadan elde edilen bulgular, matematik tarihinin kullanımının, öğrenme-öğretme sürecini destekleyici ve zenginleştirici özelliğinin yanında, ilkokuldan yükseköğretime kadar öğrenci ve öğretmenlere çok farklı katkıları olduğunu da ortaya koymuştur (Albayrak, 2011; Başıbüyük, 2012; Bayam, 2012; Bellomo ve Werheimer, 2010; Ersoy ve Öksüz, 2016; Fauvel, 1991; Hagerty, Smith ve Goodwin, 2007; Jankvist, 2009a; Kaye, 2008; Leng, 2006; Lim, 2011; Liu ve Niess, 2006).

Matematik tarihinin, öğrenme-öğretme süreciyle bütünleştirilmesini desteleyen argümanlar ve araştırma bulguları göz önüne alındığında (Fauvel, 1991; Fauvel ve Van Maanen, 2000; Jankvist, 2009), yanıtlanması gereken ilk soru "Matematiğin tarihinin, öğrenme-öğretme sürecine dâhil edilme durumunu gösteren resmi doküman nedir?" sorusudur ve bu soruya verilebilecek ilk olası cevap ise "resmi/hedeflenen" matematik dersi öğretim programı olacaktır. Posner (1995) resmi/hedeflenen programı "resmi otoriteler tarafından onaylanmış yazılı bir dokuman" (s.12) olarak tanımlamıştır. Benzer şekilde Porter ve Smitson (2001, s.2) resmi programı, "standartlar, çerçeveler veya yönergeler doğrultusunda öğretmenden uygulamaya aktarması beklenilen" politik bir belge olarak betimlemişlerdir. $\mathrm{Bu}$ bağlamda, resmi/hedeflenen program öğrencilerden neyi, nasıl öğreneceklerini ve aynı zamanda öğretmenlerden ise neyi, nasıl öğreteceklerini ve değerlendireceklerini belirleyen resmi yazılı belge olarak tanımlanabilir. Yukarıda sorulan soruya ilişkin olarak verilebilecek ikinci olası cevap, hem programı hem de öğretimi destekleyici materyallerden biri olan "ders kitaplarıdır." Mullis, Martin, Foy, ve Arora'nın araştırmasına göre (2012), matematik ders kitapları birçok ülkede öğretmenlerin en sık kullandığı temel öğretim materyallerindendir. Alan yazındaki araştırmalar matematik ders kitaplarının, hedeflenen programın, sınıfta öğrenme fırsatlarına dönüştürülmesinde üstlendiği merkezi rolü açıkça göstermektedir (Arseven, 2003; Başer, 2012; Collopy, 2003; Fan, Zhu, ve Miao, 2013; Reys, Reys, Lapan, Holliday, ve Wasman, 2003; Tan-Şişman ve Akkaya, 2017; Tyson ve Woodward, 1989; Woodward ve 201 
Elliott, 1990). Valverde, Bianchi, Wolfe, Schmidt ve Houang (2002) ders kitaplarını "potansiyel olarak uygulanan program" ifadesi ile tanımlayarak, resmi program ve uygulanan program arasında bir köprü görevi üstlendiğini ifade etmişlerdir. Bu bağlamda, program ve ders kitapları, matematik eğitiminde matematik tarihinin karar vericiler ve program geliştirme komisyonu tarafından nasıl ve ne düzeyde dikkate alındığını gösteren temel bileşenler olarak düşünülebilir.

Matematik tarihinin matematik eğitiminde kullanımı, özellikle Fauvel ve Van Maanen (2000) editörlüğünde hazırlanan "Matematik Eğitiminde Tarih: Bir ICMI Çalışması" adlı kitabın yayınlanmasından sonra giderek artan bir ilgi görmeye devam etse de, hem program hem de ders kitaplarındaki matematik tarihine ilişkin yürütülen araştırmaların oldukça sınırlı olduğu görülmektedir (Ho, 2008; Xenofontos ve Papadopoulos, 2015). Tablo 1'de verildiği gibi, matematik tarihinin matematik eğitiminde kullanımına ilişkin yapılan güncel çalışmaların farklı katılımcılarla (örneğin ortaokul öğrencileri, matematik öğretmenleri, vb.), çeşitli araştırma yöntemleri (örneğin niteliksel, niceliksel ve karma) ile farklı yönlere (örneğin inançlar, tutumlar, bilgi düzeyi, vb.) odaklandığı görülmektedir.

Tablo 1.

Matematik tarihinin matematik eğitiminde kullanımına ilişkin yapılan güncel çalışmalar

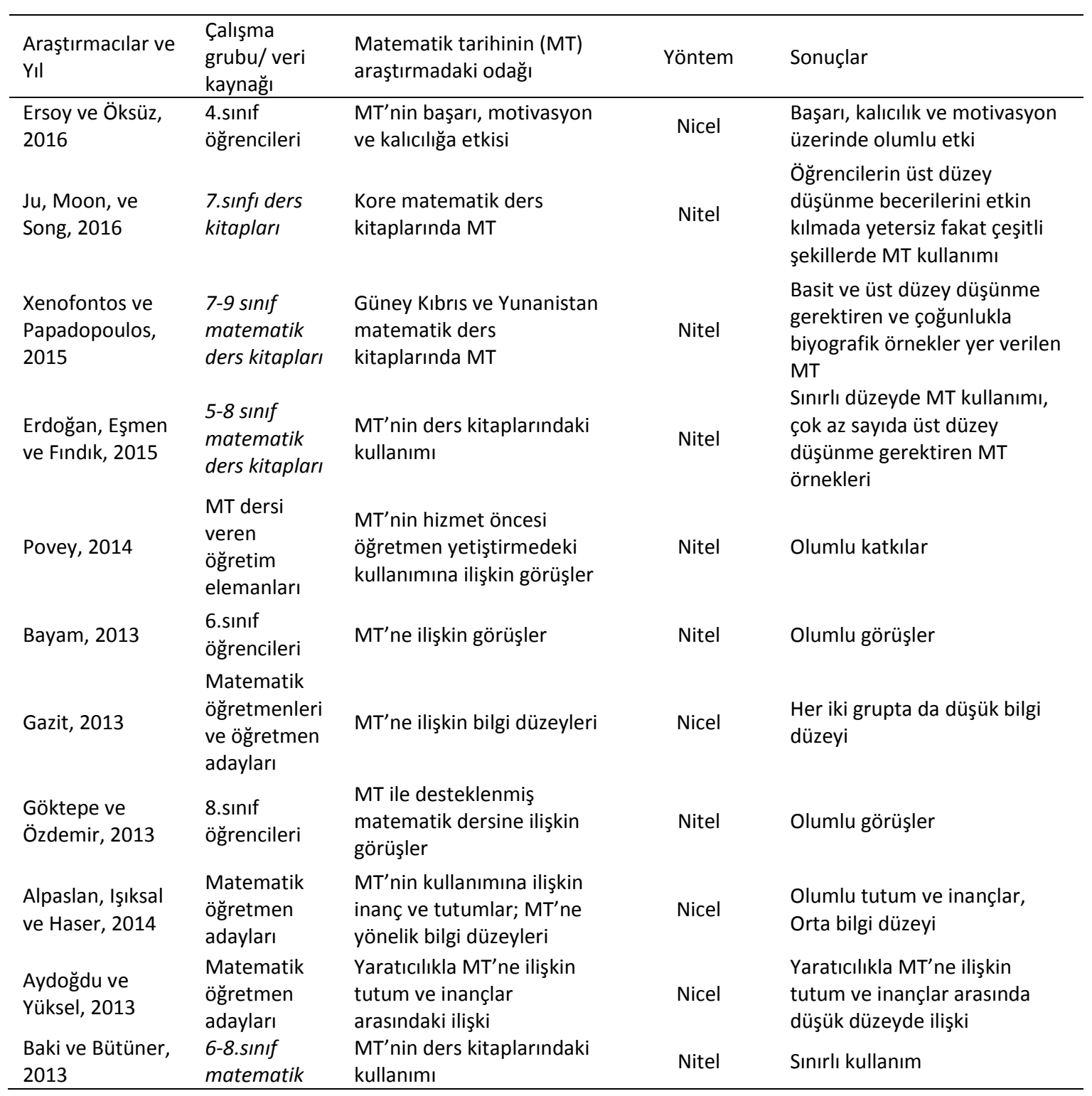


Tablo 1.

Matematik tarihinin matematik eğitiminde kullanımına ilişkin yapılan güncel çalışmalar (devamı)

\begin{tabular}{|c|c|c|c|c|}
\hline $\begin{array}{l}\text { Araştırmacılar ve } \\
\text { Y,l }\end{array}$ & $\begin{array}{l}\text { Çalışma grubu/ } \\
\text { veri kaynağı }\end{array}$ & $\begin{array}{l}\text { Matematik tarihinin (MT) } \\
\text { araştırmadaki odağı }\end{array}$ & Yöntem & Sonuçlar \\
\hline Bayam, 2012 & $\begin{array}{l}\text { 6.sınıf } \\
\text { öğrencileri }\end{array}$ & $\begin{array}{l}\text { MT'nin başarı ve tutum } \\
\text { üzerindeki etkisi }\end{array}$ & Karma & $\begin{array}{l}\text { Sadece başarı üzerinde } \\
\text { olumlu etki }\end{array}$ \\
\hline Başıbüyük, 2012 & $\begin{array}{l}\text { Üniversite } \\
\text { öğrencileri }\end{array}$ & $\begin{array}{l}\text { MT destekli öğretimin başarı } \\
\text { ve tutum üzerindeki etkisi }\end{array}$ & Nicel & $\begin{array}{l}\text { Başarı ve tutum üzerinde } \\
\text { olumlu etki }\end{array}$ \\
\hline $\begin{array}{l}\text { Özdemir, } \\
\text { Göktepe ve } \\
\text { Kepçeoğlu, } 2012\end{array}$ & $\begin{array}{l}\text { 11.sınıf } \\
\text { öğrencileri }\end{array}$ & $\begin{array}{l}\text { MT'nin geometrik } \\
\text { ispatlamada kullanımı }\end{array}$ & Nitel & $\begin{array}{l}\text { Geometrik ispatlama } \\
\text { becerilerinde gelişim }\end{array}$ \\
\hline $\begin{array}{l}\text { Panasuk ve } \\
\text { Horton, } 2012\end{array}$ & $\begin{array}{l}\text { Matematik } \\
\text { öğretmenleri }\end{array}$ & $\begin{array}{l}\text { MT'ne ilişkin algılar ve MT } \\
\text { kullanımını etkileyen faktörler }\end{array}$ & Nicel & $\begin{array}{l}\text { MT'ne ilişkin yetersiz bilgi } \\
\text { düzeyi ve düşük özgüven } \\
\text { MT faktörleri: Zaman } \\
\text { kısıtlaması, materyal eksikliği, } \\
\text { sınavlarda MT'nin olmaması, }\end{array}$ \\
\hline Clark, 2012 & $\begin{array}{l}\text { Matematik } \\
\text { öğretmen } \\
\text { adayları }\end{array}$ & $\begin{array}{l}\text { MT'nin pedagojik alan } \\
\text { bilgisine katkısı }\end{array}$ & Nitel & Olumlu katkı \\
\hline Yenilmez, 2011 & $\begin{array}{l}\text { Matematik } \\
\text { öğretmen } \\
\text { adayları }\end{array}$ & MT dersine ilişkin görüşler & Nicel & Olumlu görüşler \\
\hline Burns, 2010 & $\begin{array}{l}\text { Matematik } \\
\text { öğretmen } \\
\text { adayları }\end{array}$ & $\begin{array}{l}\text { MT'nin lise matematik } \\
\text { eğitiminde kullanımına ve } \\
\text { rolüne ilişkin görüşlerdeki } \\
\text { değişimler }\end{array}$ & Karma & $\begin{array}{l}\text { MT'nin kullanımı ve rolüne } \\
\text { ilişkin görüş ve inançlarda } \\
\text { olumlu değişimler }\end{array}$ \\
\hline Gürsoy, 2010 & $\begin{array}{l}\text { Matematik } \\
\text { öğretmen } \\
\text { adayları }\end{array}$ & $\begin{array}{l}\text { MT'nin kullanımına ilişkin } \\
\text { tutum ve inançlar }\end{array}$ & Karma & Olumlu tutum ve inançlar \\
\hline $\begin{array}{l}\text { Huntley ve } \\
\text { Flores, } 2010\end{array}$ & $\begin{array}{l}\text { Matematik } \\
\text { öğretmen } \\
\text { adayları }\end{array}$ & $\begin{array}{l}\text { MT dersinin pedagojik alan } \\
\text { bilgisine katkısına ilişkin } \\
\text { görüşler }\end{array}$ & Nitel & Olumlu katkılar ve görüşler \\
\hline Jankvist, 2010 & Lise öğrencileri & $\begin{array}{l}\text { Matematiğin meta-konularına } \\
\text { ve tarihine dair düşüncelerde } \\
\text { değişimler }\end{array}$ & Nicel & Olumlu değişimler \\
\hline $\begin{array}{l}\text { Thomaidis ve } \\
\text { Tzanakis, } 2009\end{array}$ & $\begin{array}{l}\text { 7-9.sınıf } \\
\text { matematik } \\
\text { ders kitapları }\end{array}$ & $\begin{array}{l}\text { Yunanistan lise matematik } \\
\text { ders kitaplarında MT'nin } \\
\text { kullanımı }\end{array}$ & Nitel & $\begin{array}{l}\text { Çok sayıda MT kullanımı, } \\
\text { ancak MT kullanımının hatalı, } \\
\text { belirsizlik yaratan veya eksik } \\
\text { bilgi içermesi }\end{array}$ \\
\hline $\begin{array}{l}\text { Baki ve Güven, } \\
2009\end{array}$ & $\begin{array}{l}\text { Matematik } \\
\text { öğretmen } \\
\text { adayları }\end{array}$ & $\begin{array}{l}\text { Khayyam Metodu ile ikinci } \\
\text { dereceden denklem } \\
\text { çözümünde dinamik geometri } \\
\text { programının kullanımı ile ilgili } \\
\text { deneyimler }\end{array}$ & Nicel & $\begin{array}{l}\text { Khayyam'ın katkılarına ilişkin } \\
\text { farkındalık, olumlu } \\
\text { deneyimler, geçmiş ve } \\
\text { günümüzdeki matematikle } \\
\text { bağlantılar }\end{array}$ \\
\hline Smestad, 2008 & $\begin{array}{l}\text { Matematik } \\
\text { öğretmenleri }\end{array}$ & $\begin{array}{l}\text { Programdaki MT'ne ilişkin } \\
\text { bakış açıları }\end{array}$ & Nitel & $\begin{array}{l}\text { Programdaki MT'ye ilişkin } \\
\text { farklı kavramsallaştırmalar ve } \\
\text { uygulamalar }\end{array}$ \\
\hline Tözluyurt, 2008 & Lise öğrencileri & $\begin{array}{l}\text { MT destekli öğretime ilişkin } \\
\text { görüşler }\end{array}$ & Nitel & Olumlu görüşler \\
\hline İdikut, 2007 & $\begin{array}{l}\text { 7.sınıf } \\
\text { öğrencileri }\end{array}$ & $\begin{array}{l}\text { MT'nin başarı ve tutuma } \\
\text { etkisi }\end{array}$ & Nicel & $\begin{array}{l}\text { Sadece başarıya ilişkin olumlu } \\
\text { etki }\end{array}$ \\
\hline Smestad, 2000 & $\begin{array}{l}\text { Norveç } \\
\text { matematik }\end{array}$ & $\begin{array}{l}\text { Norveç ders kitaplarında MT } \\
\text { kullanımı }\end{array}$ & Nitel & $\begin{array}{l}\text { Çok sınırlı MT kullanımı, } \\
\text { bazılarında yanlış ve hatalı }\end{array}$ \\
\hline
\end{tabular}



düşüncenin, tarihsel temellerine odaklanan oldukça sınırlı sayıda çalışma (Baki ve Bütüner, 2013; Erdoğan, Eşmen ve Fındık, 2015; Smestad, 2000; Thomaidis ve Tzanakis, 2009; Xenofontos ve Papadopoulos, 2015) bulunmaktadır. Ayrıca, matematik tarihini konu alan çeşitli raporlarda, gerek ilkokul gerekse ortaokul matematik programları ve ders kitaplarında matematiğin tarihsel boyutunun bütünleştirilmesine ilişkin gösterilen çabanın yetersiz olduğu vurgulanmaktadır (Ho, 2008; Radford, Furingetti ve Katz, 2007; Xenofontos ve Papadopoulos, 2015). Bu bilgiler ışığında, bu araştırmanın amacı, 2013 ortaokul matematik dersi $(5,6,7$ ve 8.sınıflar) öğretim programında ve ortaokul matematik ders $(5,6,7$ ve 8.sınıflar) kitaplarında, matematik tarihine nasıl yer verildiğinin incelenmesidir. Bu kapsamda araştırmada yanıt aranan sorular şunlardır:

1. 2013 Ortaokul Matematik Dersi (5-8.sınıflar) Öğretim Programının temel öğelerinde (kazanımlar, içerik, eğitim durumları ve sınama durumları) matematik tarihine nasıl yer verilmiştir?

\section{Ortaokul matematik ders (5-8.sınıflar) kitaplarında matematik tarihine nasıl yer verilmiştir?}

$\mathrm{Bu}$ araştırmadan elde edilen bulguların, matematik dersi öğretim programı ve ders kitaplarının, matematik tarihi perspektifinden yansımalarına odaklanan program geliştirme uzmanlarına, akademisyenlere ve matematik öğretmenlerine önemli katkılar sunması beklenmektedir. Ayrıca, Türkiye'de ortaokul matematik eğitimindeki matematik tarihinin durumuna ilişkin bulgular ortaya koyması açısından da uluslararası alan yazına katkı sağlaması beklenmektedir. Diğer bir yandan, öğretim programının nasıl uygulandığı veya ders kitaplarının öğrenme-öğretme sürecinde nasıl kullanıldığı bu araştırmanın odağında yer almasa da, elde edilen bulguların resmi programda hedeflenen matematik tarihi kullanımı ile ders kitaplarında öğrenme-öğretme ortamına yansıyacak potansiyel matematik tarihi kullanımı arasındaki uyumun ortaya konmasına da yardımcı olacağı düşünülmektedir (Valverde, ve diğ., 2002). Başka bir değişle, resmi programda "amaçlanan matematik tarihi" ile ders kitaplarındaki "potansiyel olarak öğrenme-öğretme sürecine yansıyacak matematik tarihinin" ortaya konulması açısından önem taşımaktadır.

Bir sonraki bölüme geçmeden önce, araştırmanın bağlamı olan Türkiye'deki matematik eğitimine ilişkin genel bilgilerin paylaşılmasının anlamlı ve yararlı olacağı düşünülmektedir. Yönetsel açıdan oldukça merkezi bir yapıya sahip Türk eğitim sisteminde, Milli Eğitim Bakanlığı (MEB), program geliştirme ve ders kitaplarının onaylanması dâhil olmak üzere tüm eğitim hizmetlerinin planlanması, programlanması, yürütülmesi, izlenmesi ve kontrol edilmesinden sorumludur. 2005 yılında, öğrenci merkezli ve yapılandırmacı öğrenme yaklaşımının benimsendiği köklü bir program reformu yapılarak, temel eğitim seviyesindeki öğretim programları yenilenmiştir. 2012 yılında uygulamaya konulan 12 yıllık zorunlu eğitim uygulamasıyla, zorunlu eğitim süresi 8 yıldan 12 yıla (4 yıl- ilkokul, 4 yıl- ortaokul ve 4 yıllise) çıkarılmıştır. Bu yapısal reformla birlikte, ikinci bir program revizyonu zorunluluk haline gelmiştir. 2013-2014 eğitim-öğretim yılında güncellenen ortaokul matematik dersi öğretim programı (5-8.sınıf) uygulamaya konulmuştur. En genel anlamda güncellenen programın amacı, öğrencilere 21. yüzyılın gerektirdiği matematiksel bilgi ve becerilerin kazandırılacağı öğrenme-öğretme ortamlarının sağlanması olarak belirlenmiştir (MEB, 2013). Güncellenen öğretim programının öğrenme alanları, Sayılar ve İşlemler, Cebir, Geometri ve Ölçme, Veri İşleme ve Olasılık olmak üzere beş temel konu alanını kapsamaktadır. Ayrıca öğrencilerin problem çözme becerileri, matematiksel süreç becerileri (örneğin akıl yürütme, iletişim, vb.) duyuşsal (tutum, özgüven, öz-düzenleme, vb.) ve psikomotor gelişimine ilişkin becerilerin desteklenmesi de önemle vurgulanmaktadır (MEB, 2013).

\section{Yöntem}

2013 ortaokul matematik dersi (5-8.sınıflar) öğretim programı ve ortaokul matematik ders (58.sınıflar) kitaplarında matematik tarihine nasıl yer verildiğinin incelenmesi amacıyla nitel desende yürütülen bu araştırmanın yanıt aradığı problemler, yazılı materyallerin içerik ve kapsamına yönelik 
olduğundan dolayı doküman incelemesi yoluyla veri toplanmıştır. Bu kapsamda, araştırmanın temel veri kaynakları, Talim ve Terbiye Kurulu Başkanlığı tarafından 2013-2014 öğretim yılından itibaren kademeli olarak uygulanmak üzere kabul edilen ortaokul matematik dersi (5-8.sınıflar) öğretim programı ile 20152016 eğitim-öğretim yılında MEB tarafından hazırlanan devlet okullarında okutulacak ortaokul matematik ders (5-8.sınıflar) kitapları listesindeki tüm ders kitaplarıdır. Araştırma kapsamında incelenen ders kitaplarına ilişkin detaylı bilgiler Tablo 2'de sunulmuştur.

Tablo 2.

Araştırma kapsamında incelenen ders kitaplarına ilişkin bilgiler

\begin{tabular}{lll}
\hline Sınıf düzeyi & Yayınevi & Toplam sayfa sayısı \\
\hline \multirow{2}{*}{ 5.sınıf } & MEB & 588 (2 cilt) \\
& Özgün & 264 \\
\hline 6.sınıf & Dikey Yayıncılık & 264 \\
\hline 7. sınıf & Tutku & 354 \\
\hline \multirow{2}{*}{ 8. sınıf } & MEB & 263 \\
& Sevgi & 262 \\
\hline Toplam & 6 ders kitabı & 1995 \\
\hline
\end{tabular}

Çalışmada, araştırmacılar tarafından geliştirilen iki farklı yönerge kullanılarak veri setinin analizi yürütülmüştür. Bu yönergelerden ilki olan öğretim programı analiz yönergesi, matematik tarihinin programda nerede (kazanımlar, içerik, öğrenme-öğretme süreci ve ölçme-değerlendirme) ve nasıl (zorunluluk/öneri) ele alındığının ortaya konulmasına yönelik olarak hazırlanmıştır. Tablo 3'te öğretim programı analiz yönergesi verilmiştir.

Tablo 3.

Öğretim programı analiz yönergesi

\begin{tabular}{ll}
\hline & Öğretim programının öğeleri \\
Öğretim programında matematik tarihi hangi & Kazanımlar \\
öğe kapsamında ele alınmıştır? & İçerik \\
& Eğitim durumları (Öğrenme-öğretme süreci) \\
& Sınama durumları (Ölçme-değerlendirme) \\
\hline \multirow{2}{*}{$\begin{array}{l}\text { Öğretim programında matematik tarihi nasıl ele } \\
\text { alınmıştır? }\end{array}$} & Yansıtılma şekli \\
\hline
\end{tabular}

Tablo 4'te verilen ikinci yönerge ise, ders kitaplarında matematik tarihinin nerede ve nasıl kullanıldığının incelenmesi amacıyla geliştirilmiştir. Yönergenin ilk kısmı, ders kitaplarının hangi bölümlerinde (örn: ünite/konu başlangıcında, konu anlatımında, konu sonunda veya ek bilgi olarak) matematik tarihine yer verildiğinin tespit edilmesine yöneliktir. Yönergenin ikinci kısmında ise, ders kitaplarında matematik tarihinin nasıl kullanıldığının ortaya konulmasına amaçlanmıştır. Bu bölümdeki sınıflandırmalar, Xenofontos and Papadopoulos'un (2015) (1) basit tarihi/biyografik örnekler; (2) bir formül veya kuralın ispatında/çözümünde kullanılan tarihi öğeler; (3) bilişsel öğelerden oluşan bir matematiksel çözüm, açıklama ya da ispat gerektiren matematik tarihi içeren matematiksel görevler ve (4) matematik tarihi ile günlük yaşamdaki matematiği ilişkilendiren tartışma veya projeler olarak geliştirdiği kategoriler kapsamında oluşturulmuştur. 
Tablo 4.

Matematik ders kitapları analiz yönergesi

\begin{tabular}{ll}
\hline & Kullanım yeri \\
Matematik tarihine ilişkin öğelere ders & Ünite/konu başlangıcında (e.g. giriş etkinlikleri) \\
kitaplarının hangi bölümünde yer verilmiştir? & Konu anlatımı \\
& Konu sonunda (örn: kalıcılık, transfer vb. ) \\
& Ek bilgi (konu dışı bilgi) \\
\hline & Kullanım şekli \\
& Basit tarihi/biyografik örnekler \\
Matematik tarihine ilişkin öğeler ders & Formül veya kuralın ispatında/çözümüne yönelik \\
kitaplarında nasıl ele alınmıştır? & açıklamalar \\
& Matematiksel görevler \\
& Tartışma/projeler \\
\hline
\end{tabular}

Bu yönergeler doğrultusunda ortaokul matematik dersi öğretim programı ve ortaokul matematik ders kitaplarındaki matematik tarihine ilişkin tüm referansların ortaya konulması amacıyla araştırmacılar tarafından satır satır incelenmiştir. Veri analizi sürecinde, tüm veri seti araştırmacılar tarafından yönergeler doğrultusunda ayrı ayrı kodlandıktan sonra, elde edilen kodlamalar birbiriyle karşılaştırılarak uyumluğu kontrol edilmiştir.

\section{Bulgular}

Ortaokul matematik dersi öğretim programındaki ve matematik ders kitaplarındaki matematik tarihinin kullanımına ilişkin olarak yürütülen veri analizinden elde edilen bulgular, araştırma soruları paralelinde sunulmuştur.

\section{Ortaokul Matematik Dersi Öğretim Programında Matematik Tarihinin Yeri}

Ortaokul matematik dersi öğretim programında (OMÖP) yer verilen matematik tarihiyle ilgili tüm bileşenlerin ortaya konulmasına amacıyla kazanımlar, içerik, eğitim durumları ve sınama durumları kapsamında yapılan içerik analizinden elde edilen bulgular Tablo 5 'te özetlenmiştir.

Tablo 5.

Öğretim programında yer verilen matematik tarihine ilişkin bulgular

\begin{tabular}{llc}
\hline Programın öğeleri & Programdaki kullanımı & Kullanım şekli \\
\hline Kazanımlar & 6.1.2.3 nolu kazanıma ilişkin açıklama & Zorunlu \\
İçerik (öğrenme alanları) & Hiçbir göstergeye rastlanamamıştır. & ----- \\
Eğitim durumları & Ünlü matematikçilerin biyografileri ve matematiğe olan & Öneri \\
(Öğrenme-öğretme süreci) & katkılarının derslerde kullanımına yönelik öneriler & ------ \\
Sınama durumları & Hiçbir göstergeye rastlanamamıştır & (Ölçme-değerlendirme) \\
\hline
\end{tabular}

5-8.sınıf kazanımları incelendiğinde, matematik tarihine ilişkin tek örnek "Asal sayıları özellikleriyle belirler" kazanımına ait açıklamada (Şekil 1) ifade edilen "Erastosten Kalburu" yardımıyla asal sayıların özelliklerinin bulunmasıdır. Açıklama ifadesi incelendiğinde, Erastosten Kalburu'nun kullanımı bir öneriden çok, mutlaka yer verilmesi gereken bir durum olarak ifade edilmiştir.

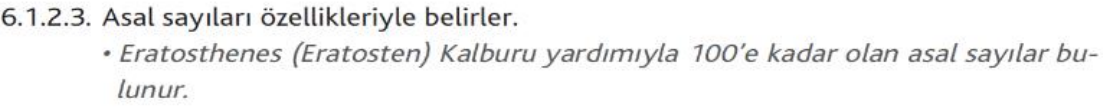

Şekil 1. Erastosten Kalburu'nun kullanımını içeren kazanım ve açıklaması (OMÖP,2013; 6.sınıf, s. 13) 
Öğretim programının içerik öğesi kapsamında sayılar ve işlemler, cebir, geometri ve ölçme, veri işleme ve olasılık olmak üzere beş temel öğrenme alanında matematik tarihine ilişkin hiçbir ifadeye rastlanılmamıştır. Tablo 5 'te verildiği gibi, eğitim durumları (öğrenme-öğretme süreci) öğesinde "Programda Matematiğin Gelişimine ilişkin Bilgilendirmelerin Kullanılması" başlığı (Şekil 2) altında ünlü matematikçilerin biyografilerinin, matematiğe olan katkılarının dersler de ele alınmasının öğrencilerin matematiğe yönelik olumlu tutum geliştirmesini sağlayacağı ifade edilmiştir. Ayrıca Atatürk'ün matematik alanına sağladığı katkılara da matematik öğretimi sürecinde yer verilmesi vurgulanmıştır. Eğitim durumlarında matematik tarihinin yansıtılma şekline ilişkin ifadeler incelendiğinde ise, bu ifadelerin öğretmenlere sunulan öneri ve tavsiye niteliğinde olduğu görülmüştür. Öğretim programının ölçme-değerlendirme durumlarında ise matematik tarihine ilişkin bir göstergeye rastlanamamıştır.

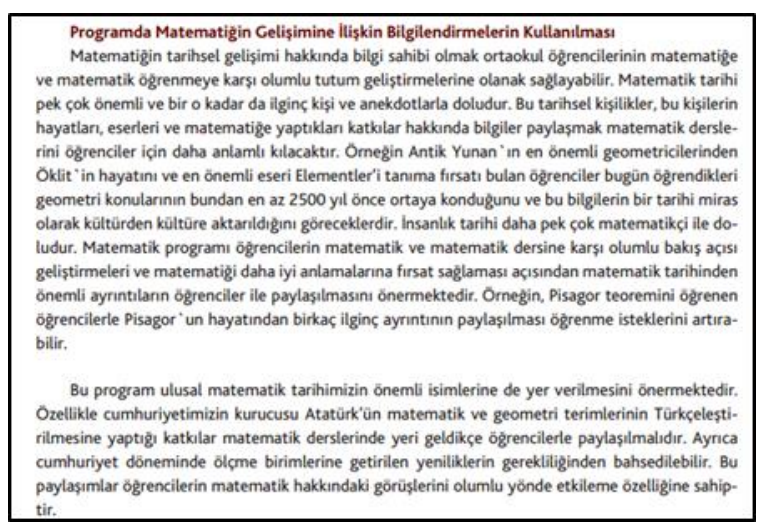

Şekil 2. Programda Matematiğin Gelişimine ilişskin Bilgilendirmelerin Kullanılması (OMÖP), 2013 s. VIII)

\section{Ortaokul Matematik Ders Kitaplarında Matematik Tarihinin Yeri}

Araştırma kapsamında incelenen 6 ortaokul matematik ders kitabındaki matematik tarihine ilişkin tüm örneklerin ortaya konulmasına yönelik olarak yürütülen içerik analizinden elde edilen bulgulara göre, tüm sınıf seviyeleri (5-8.sınıflar) kapsamında incelenen toplam 1995 sayfadan, matematik tarihine ilişkin örneklerin yer verildiği toplam sayfa sayısı 35'tir. Analiz kapsamına dâhil edilen toplam 6 ortaokul matematik ders kitabında tespit edilen matematik tarihine ilişkin toplam örnek sayısı ise sadece $27^{\prime}$ dir. Ders kitaplarının analizinden elde edilen bulgular Tablo 6'da özetlenmiştir.

Tablo 6.

Ders kitaplarında tespit edilen matematik tarihine ilişkin bulgular

\begin{tabular}{lccccc}
\hline Kullanım yeri & $\begin{array}{c}\text { Basit tarihi/ } \\
\text { biyografik } \\
\text { örnekler }\end{array}$ & $\begin{array}{c}\text { Formül/kuralınım şekli } \\
\text { ispatında/ } \\
\text { çözümüne yönelik } \\
\text { açıklamalar }\end{array}$ & $\begin{array}{c}\text { Matematiksel } \\
\text { görevler }\end{array}$ & $\begin{array}{c}\text { Tartışma/ } \\
\text { projeler }\end{array}$ & Toplam \\
\hline Konu başlangıcında & 9 & - & 3 & 2 & 14 \\
Konu anlatımı & - & 3 & - & - & 3 \\
Konu sonunda & 6 & - & 1 & - & 7 \\
Ek bilgi/konu dışı bilgi & 3 & - & - & - & 3 \\
Toplam & 18 & 3 & 4 & 2 & 27 \\
\hline
\end{tabular}


Ders kitaplarında yer verilen matematik tarihine ilişkin örneklerin sınıf düzeyleri açısından dağılımı incelendiğinde, en fazla örneğe $(f=12)$ 8. sınıf matematik ders kitaplarında rastlanılmıştır. Tablo 7'de verildiği gibi, 7.sınıf matematik ders kitabında, matematik tarihine yönelik hiçbir bulguya rastlanamazken; 6.sınıfta sekiz; 5.sınıf matematik ders kitaplarında ise yedi gösterge tespit edilmiştir.

Tablo 7.

Ders kitaplarında yer verilen matematik tarihine ilişkin göstergelerin sınıf düzeyine göre dağılımı

\begin{tabular}{|c|c|c|c|c|c|}
\hline \multirow[b]{2}{*}{$\begin{array}{l}\text { Sınıf } \\
\text { düzeyi }\end{array}$} & \multicolumn{4}{|c|}{ Kullanım yeri } & \multirow[b]{2}{*}{ Toplam } \\
\hline & Konu başlangıcında & Konu anlatımında & Konu sonunda & Ek bilgi & \\
\hline 5.sınıf & - & - & 7 & - & 7 \\
\hline 6.sınıf & 4 & 1 & - & 3 & 8 \\
\hline 7.sınıf & - & - & - & - & - \\
\hline 8.sinif & 10 & 2 & - & - & 12 \\
\hline Toplam & 14 & 3 & 7 & 3 & 27 \\
\hline
\end{tabular}

İçerik analizinden elde edilen bulgulara göre, ders kitaplarından matematik tarihi en fazla konu başlangıçlarında kullanılmıştır. Matematik tarihinin konu başlangıcında kullanımına ilişkin örneklere Şekil 3 ve 4 'te yer verilmiştir.

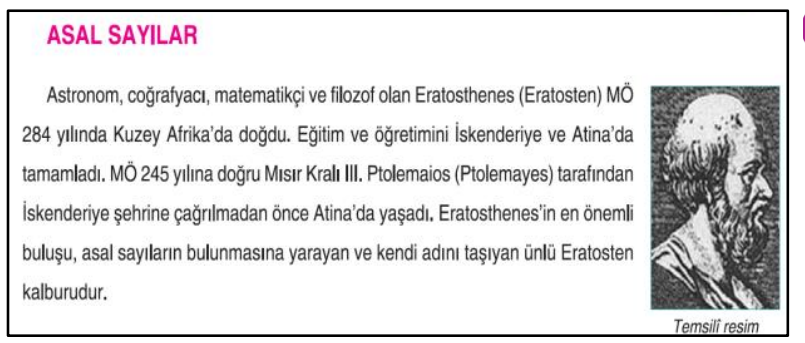

Şekil 3. Erastosten'in kısa biyografisi,

(Dikey, 6.sınıf, s. 39)

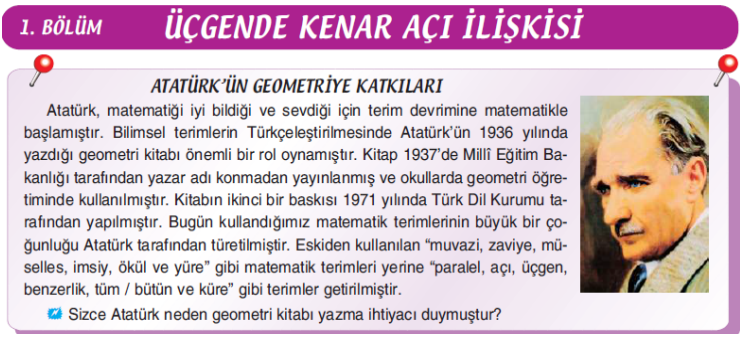

Şekil 4. Atatürk'ün geometireye katkıları (Sevgi, 8.sınıf, s. 82)

6.sınıf ders kitabında tespit edilen bir örnek ve 8.sınıf ders kitabında tespit edilen iki örnek dışında, matematik tarihinin, konu anlatımında kullanıldığı herhangi bir örneğe rastlanılmamıştır. Şekil 5'te 6.sınıf ders kitabında yer verilen Erastosten Kalburu'nun asal sayılar konusunun açıklamasındaki kullanımı ve Şekil 6'da ise 8.sınıf ders kitabındaki Paskal Üçgeninin oluşturulmasına ilişkin verilen açıklama sunulmuştur.

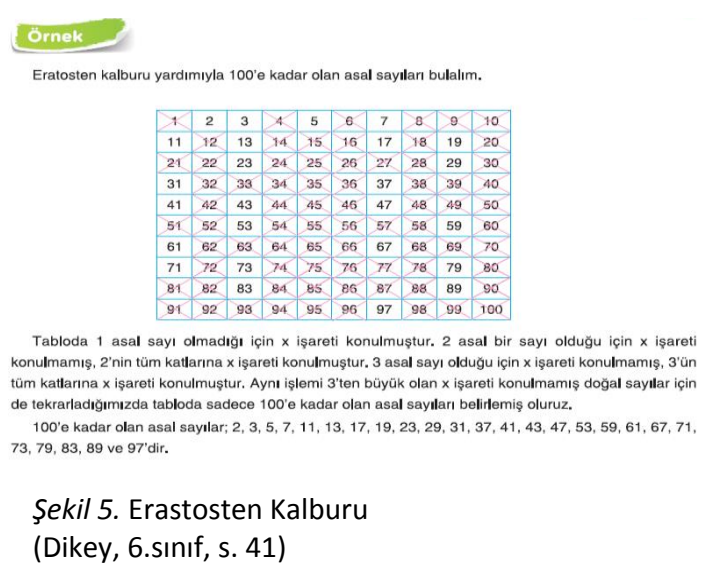

(Dikey, 6.sınıf, s. 41)

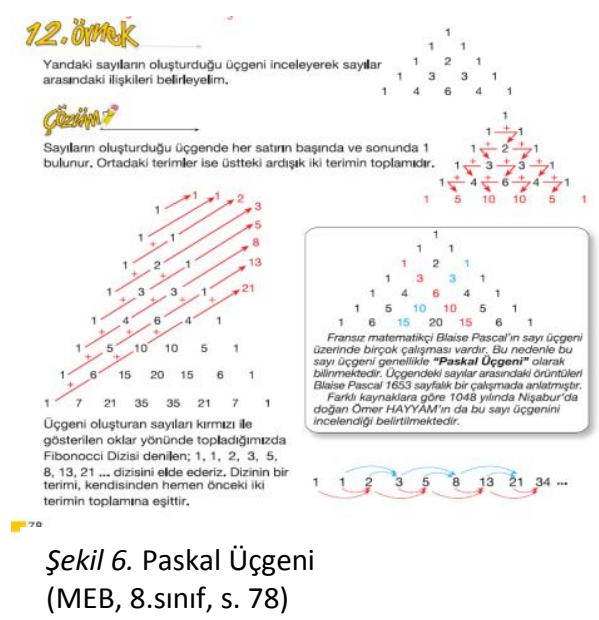

208 
Bunlara ek olarak, matematik tarihinin konu sonunda kullanımına ilişkin örneklere sadece 5.sınıf ders kitaplarında rastlanmıştır. Şekil 7'de veri analizi ve yorumlama konusunun sonunda Wiliam Playfair ve sütun grafiğine ilişkin açıklamaların yer aldığı; Şekil 8'de de parantez işaretinin matematikte kullanımına ilişkin açıklamaların yer aldığı örnekler sunulmuştur.

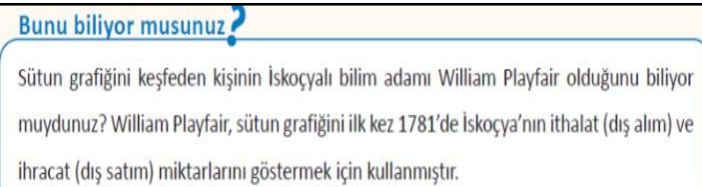

Şekil 7. Wiliam Playfair ve sütun grafiği

(MEB, 5.sınıf, s. 127)

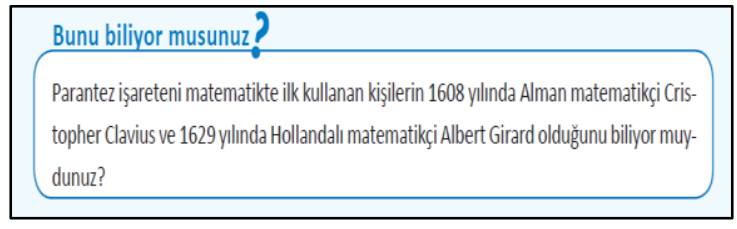

Şekil 8. Parantez işaretinin matematikte kullanımı (MEB, 5.sinif, s. 61)

Ders kitaplarında matematik tarihinin ek bilgi veya konu dışı bilgi olarak kullanımına ilişkin sadece 6.sınıf düzeyinde 3 örnek tespit edilmiştir. Şekil 9'da dünyaca ünlü Türk matematikçi Cahit Arf'in biyografisi, veri analizi konusunun sonunda ek bilgi olarak verilmiştir.

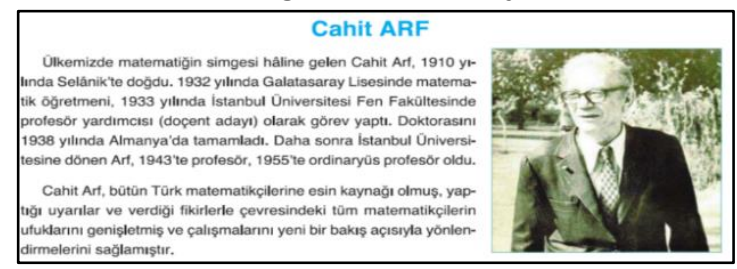

Şekil 9. Cahit Arf (Dikey, 6.sınıf, s. 151)

Matematik tarihine ilişkin öğelerin ders kitaplarında kullanım şekline ilişkin elde edilen bulgularda ise çoğunlukla basit tarihi veya biyografik bilgiler şeklinde kullanıldığı görülmüştür. Tablo 8'de verildiği gibi, ders kitaplarında tespit edilen toplam 27 örnekten 18'i matematik tarihinin basit tarihi veya biyografik bilgiler formunda yansıtıldığını göstermektedir.

\section{Tablo 8.}

Ders kitaplarında yer verilen matematik tarihinin kullanım şekline ilişkin bulgular

\begin{tabular}{|c|c|c|c|c|c|}
\hline \multirow[b]{2}{*}{$\begin{array}{l}\text { Sınıf } \\
\text { düzeyi }\end{array}$} & \multicolumn{5}{|c|}{ Kullanım şekli } \\
\hline & $\begin{array}{c}\text { Basit tarihi/ biyografik } \\
\text { örnekler }\end{array}$ & $\begin{array}{c}\text { Formül/kuralın } \\
\text { ispatında/çözümüne } \\
\text { yönelik açıklamalar }\end{array}$ & $\begin{array}{l}\text { Matematiksel } \\
\text { görevler }\end{array}$ & $\begin{array}{l}\text { Tartışma/ } \\
\text { projeler }\end{array}$ & Toplam \\
\hline 5.sinıf & 6 & - & 1 & - & 7 \\
\hline 6.sınıf & 5 & 1 & 1 & 1 & 8 \\
\hline 7.sınıf & - & - & - & - & - \\
\hline 8.sınıf & 7 & 2 & 2 & 1 & 12 \\
\hline Toplam & 18 & 3 & 4 & 2 & 27 \\
\hline
\end{tabular}

Matematik tarihinin basit tarihi veya biyografik bilgiler formunda kullanımına ilişkin örnekler Şekil 10 ve Şekil 11 'de sunulmuştur.

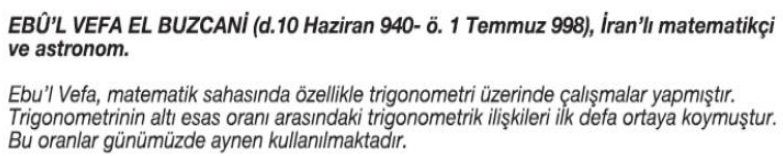

Ebu'l Vefa, matematik sahasında özellikle trigonometri üzerinde calısmalar yapmıstır. Trigonometrinin altı esas oranı arasındaki trigonometrik ilişkileri ilk defa ortaya koymuștur. Bu oranlar günümüzde aynen kullanılmaktadir.

Şekil 10. Ebü'I Vefa El Buzcani, (MEB, 8.sınıf, s. 145)

\section{Ali KUȘçU}
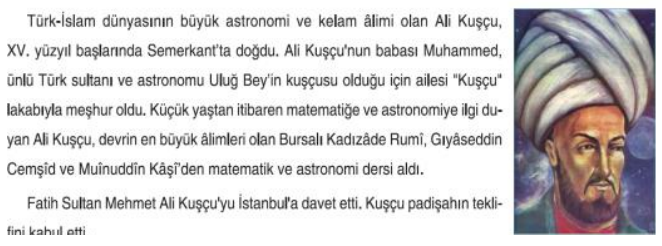

Şekil 11. Ali Kuşçu, (Dikey, 6.sınıf, s. 127) 
Ders kitaplarından elde edilen diğer bir bulgu ise, matematik tarihinin bir formül veya kuralın ispatında çözümünde destekleyici bir unsur olarak kullanımının sınırlı olduğudur. Şekil 5 ve Şekil 6 'da verilen örnekler bu kullanım türüne ilişkin örneklerdir. Bu bulguya ek olarak, ders kitaplarında öğrencilerin matematik tarihini deneyimlemesine ilişkin sunulan fırsatlarında oldukça yetersiz olduğu tespit edilmiştir. Bu bağlamda, matematik tarihinin öğrenciden bir matematiksel çözüm, açıklama ya da ispat yapmasını gerektiren matematiksel görevler kapsamında kullanımına ilişkin sadece 4 örnek tespit edilirken; matematik tarihi ile günlük yaşamdaki matematiği ilişkilendiren tartışma/projelerin kullanımına ilişkin sadece 2 örneğe rastlanmıştı. Bunlara ilişkin olarak Şekil 12'de verilen örnekte, matematiksel görev olarak öğrencilerden Pisagor Bağıntısı kuralının açıklanması istenirken; Şekil 13'te ise Eski Mısırıların kullandığı sayı sistemine ilişkin kısa bir açıklama verildikten sonra öğrencilerden bu sistemi kullanarak dört işlem yapmanın zorlukları neler olabilir sorusu yöneltilmiştir. Bu tartışma sorusunun cevaplanabilmesi için öğrencilerin hem Eski Mısırıların kullandığı sayı sistemi hakkında bilgi edinmelerini hem de günümüzdeki kullanımına ilişkin değerlendirmeler yapmaları istenmektedir.

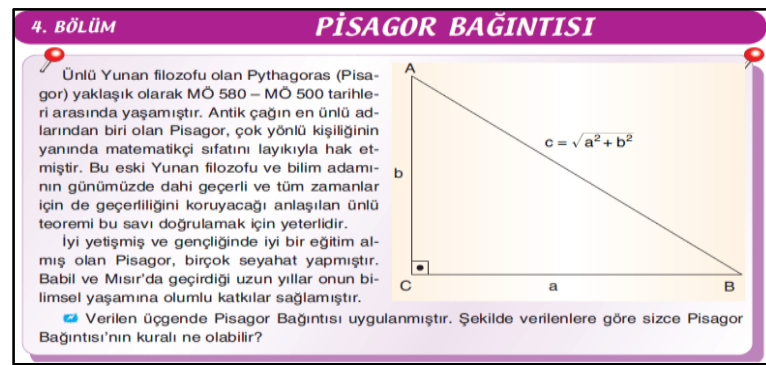

Şekil 12. Pisagor Bağıntısı,

(Sevgi, 8.sınıf, s. 110)

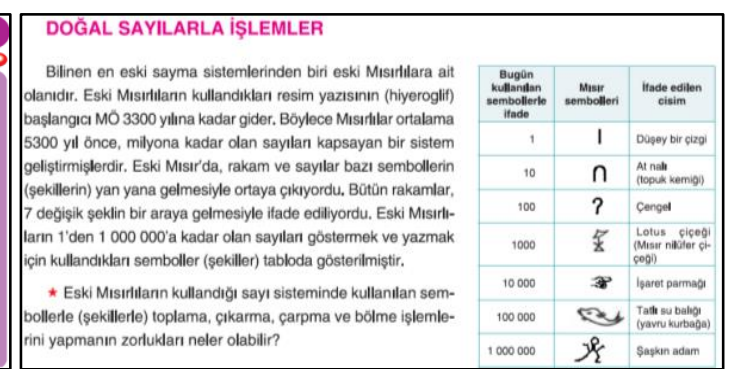

Şekil 13. Eski Mısırılarda sayı sistemi

(Dikey, 6.sınıf, s. 15)

\section{Tartışma ve Sonuç}

Matematik tarihinin, ortaokul matematik dersi (5-8.sınıflar) öğretim programı ve ortaokul matematik ders (5-8.sınıflar) kitaplarındaki durumunun incelenmesi amacıyla yürütülen bu çalışmadan elde edilen bulgular, hem program hem de ders kitaplarında matematiğin tarihsel boyutuna yer verildiğini göstermiştir. Öğretim programıın kazanımlarına ilişkin elde edilen sonuçlarda, sadece tek bir kazanıma ait açıklamada doğrudan matematik tarihine yer verildiği tespit edilmiştir. Eğitim durumlarında ise "Programda Matematiğin Gelişimine İlişkin Bilgilendirmelerin Kullanılması" başlığı altında matematik tarihinin kullanımını destekleyici öneriler sunulmuştur. İçerik ve ölçme-değerlendirme öğelerinde ise matematik tarihine ilişkin hiçbir duruma rastlanılamamıştır. Elde edilen bu sonuçlara göre, öğretim programında matematik tarihinin matematik eğitimindeki rolünün dikkate alınmasına rağmen, matematik tarihinin programın öğeleriyle tam ve kapsamlı olarak bütünleştirilemediği açıktır. Bu sonuç, programın kazanımlarından, değerlendirme öğesine kadar tüm öğelerinde matematik tarihinin dengeli bir şekilde harmanlanması gerektiğine işaret etmektedir. Matematik tarihiyle bütünleştirilmiş bir öğretim programı, öğrencilere anlamlı öğrenme deneyimlerinin sağlanmasında oldukça önemlidir. Lingard'ın (2000) da ifade ettiği gibi "Matematik tarihinin programa dâhil edilmesi öğrenci motivasyonunu ve başarısını arttıracak, matematiğin gelişime açık yapısına vurgu yapacak ve matematiğin çok kültürlü mirasını ve konuların kültürel boyutunun takdir etmesini sağlayacaktır." (s. 16). Benzer şekilde Bidwell (1993) matematik tarihine yer vermeyen öğretimi "ada" metaforu ile özdeşleştirerek, bu adadaki öğrencilerin matematiği "sınırları belli, cansız, duygulardan arınık ve tamamen keşfedilmiş" (s.461) olarak algıladıklarını; fakat matematik tarihinin öğretime entegrasyonu ile "öğrencilerin bu matematik adasında kurtarılarak; sonsuz, canlı, duygu dolu ve keşfedilmeyi bekleyen matematiğin anavatanına yerleştirilmelerine" yardımcı olacağını ifade etmiştir. Bu amaca yönelik olarak matematik tarihinin, öğretim programının tüm öğeleriyle ilişkilendirilmesi; aynı zamanda da öğretmenler ve ders kitabı yazarları için daha dikkat çekici hale getirilmesi önerilebilir. 
Ayrıca, çalışma kapsamında incelenen 6 ortaokul matematik ders kitaplarındaki toplam sayfa sayısının 1995 olmasına rağmen, sadece 35 sayfada matematik tarihine ilişkin göstergeye rastlanması, öğrencilerin dört yıllık ortaokul eğitimleri boyunca matematik tarihine ilişkin deneyimlerinin oldukça sınırlı olacağının en güçlü göstergelerinden biridir. Alan yazında benzer bir bulguya Norveç matematik ders kitaplarındaki matematik tarihinin incelendiği bir çalışmada da (Smestad, 2000) rastlanmıştır. Bunlara ek olarak, dersi kitaplarında matematik tarihine ilişkin tespit edilen toplam örnek sayısının sadece 27 olması, ders kitaplarındaki matematik tarihinin oldukça sınırlı olarak kullanıldığını açıkça ortaya koyan bir diğer sonuçtur. Sınıf düzeyleri dikkate alındığında ise, 7.sınıf ders kitaplarında matematik tarihine ilişkin hiçbir örneğe rastlanılamamıştır. Bu sonuçtan hareketle, 5 ve 6. sınıf öğrencilerinin sınırlı düzeyde de olsa matematiksel bir kavram, formül veya kuralın gelişimini, dayandığı temelleri matematik tarihi perspektifi açısından deneyimleme şansına sahip oldukları, 7.sınıfa geldiklerinde ise matematik tarihi ile karşılaşma şansının tamamen ortadan kalktı̆̆ı şeklinde yorumlanabilir. Diğer bir deyişle, ders kitaplarındaki bu kopukluk, öğrencilerin matematiği, tarihi yapısıyla birlikte bir bütün olarak anlamlandırma sürecini olumsuz yönde etkileyebilir.

Bunlara ek olarak, ders kitaplarında matematik tarihinin kullanımına yönelik olarak tespit edilen göstergelerin yarısından fazlasının ansiklopedik bilgiler formunda kullanıldığı görülmüştür. Alan yazındaki farklı çalışmalarda da bu sonucu destekleyen bulgular elde edilmiştir. Örneğin Xenofontos ve Papadopulos (2015), Güney Kıbrıs ve Yunanistan'da kullanılan matematik ders kitaplarında, matematik tarihinin benzer şekilde ele alındığına değinmiştir. Baki ve Bütüner'in (2013) çalışmasında elde edilen bulgularda da matematik tarihinin ders kitaplarında çoğunlukla kısa biyografik bilgiler ve matematikçilerin resimleri kapsamında yer verildiği tespit edilmiştir. Bu bağlamda araştırmadan elde edilen bu sonuçlarla, ders kitaplarında öğrencilerin matematik tarihini deneyimlemesi ve etkileşim kurmasını destekleyen örneklere nadiren yer verildiği açıkça ortaya konulmuştur. Bu durumun olası temel sebeplerinden biri öğretim programının kendisinden kaynaklı olabilir. Özellikle Türkiye gibi merkezi bir eğitim sistemine sahip olan ülkelerde, var olan tek bir resmi program yine resmi otoriterlerce onaylanmış ders kitaplarında hayat bulmaktadır. Bundan dolayı da, resmi programda yer verilen matematik tarihinin kapsamı ve derinliği, ders kitaplarında yer alacak matematik tarihi öğelerinin de derinliğinde ve çeşitliliğinde doğrudan belirleyici rol üstlenmektedir. Sonuç olarak, matematik tarihine hem öğretim programında hem de ders kitaplarında yer verilme durumunun nitelik ve nicelik açısından oldukça yüzeysel ve yetersiz olduğu görülmektedir. 


\section{References}

Albayrak, Ö. (2011). Effects of history of mathematics integrated instruction on mathematics self-efficacy and achievement. Unpublished master thesis, Boğaziçi University, İstanbul.

Alpaslan, M., Işıksal, M., \& Haser, Ç. (2014). Pre-service mathematics teachers' knowledge of history of mathematics and their attitudes and beliefs towards using history of mathematics in mathematics education. Science \& Education, 23(1), 159-183.

Arseven, A. (2003). Illköğretim 7. sınıf matematik ders kitaplarına ilişkin öğretmen, öğrenci ve uzman görüşleri. Unpublished master thesis, Hacettepe University, Ankara.

Aydoğdu, N., \& Yüksel, i. (2013). The relationship between prospective mathematics teachers' beliefs and attitudes towards history of mathematics and their creativeness level. Journal of Research in Education and Teaching, 2(4), 186-194.

Baki, A., \& Güven, B. (2009). Khayyam with Cabri: Experiences of pre-service mathematics teachers with Khayyam's solution of cubic equations in dynamic geometry environment. Teaching mathematics and Its Applications, 28, 1-9.

Baki, A., \& Bütüner, S., Ö. (2013). The ways of using the history of mathematics in $6^{\text {th }}, 7^{\text {th }}$ and $8^{\text {th }}$ grade mathematics textbooks. Elementary Education Online, 12(3), 849-872.

Başer, N. (2012). Ilköğretim öğretmenlerinin matematik ders kitaplarıı kullanma yolları ve onların öğrencilerin matematik ders kitaplarını kullanma yolları ve matematik ders kitabı hakkındaki görüşleri. (Unpublished master thesis). Middle East Technical University, Ankara

Başıbüyük, K. (2012). The use of mathematics history in mathematics courses: Ibrahim Hakkı perspective and Babylonian method sample. Unpublished master thesis, Atatürk University, Erzurum.

Bayam, S., B. (2012). The impact of a knowledge of the history of mathematics on primary school student mathematics achievement and attitudes. Unpublished master thesis, Kastamonu University, Kastamonu.

Bayam, S., B. (2013). The views of students aged 12 about activities for history of mathematics included in mathematics curriculum. Paper presented at Eighth Congress of European Research in Mathematics Education, Antalya, Turkey.

Bellomo, C., \& Wertheimer, C. (2010). A discussion and experiment on incorporating history into the mathematics classroom. Journal of College Teaching \& Learning, 7(4), 19-24.

Bidwell, J., K. (1993). Humanize your classroom with the history of mathematics. Mathematics Teacher, 86, 461-464.

Burns, B., A. (2010). Pre-service teachers' exposure to using the history of mathematics to enhance their teaching of high school mathematics. Issues in the Undergraduate Mathematics Preparation of School Teachers: The Journal, 4, 1-9.

Burton, D., M. (2003). The history of mathematics: An introduction ( $5^{\text {th }}$ ed.). New York, NY: McGraw-Hill.

Clark, K., M. (2012). History of mathematics: Illuminating understanding of school mathematics concepts for prospective mathematics teachers. Educational Studies in Mathematics, 81(1), 67-84

Collopy, R. (2003). Curriculum materials as a professional development tool: How a mathematics textbook affected two teachers' learning. The Elementary School Journal, 103(3), 287-311.

Erdoğan, A., Eşmen, E., \& Findik, S. (2015). Ortaokul matematik ders kitaplarında matematik tarihinin yeri: ekolojik bir analiz. Marmara University Atatürk Eğitim Fakültesi Eğitim Bilimleri Dergisi, 42(42), 239-259.

Ernest, P. (1998). The history of mathematics in the classroom. Mathematics in School, 27(4). 25-31.

Ersoy, E., \& Öksüz, C. (2016). İlkokul 4. sınıflarda matematik tarihi kullanımının öğrenciler üzerindeki etkileri. Illköğretim Online, 15(2). 
Gülçin TAN-SISMAN \& Büşra KíREZ- Çukurova Üniversitesi Eğitim Fakültesi Dergisi, 47(1), 2018, 188-215

Eves, H. (1990). An introduction to the history of mathematics ( $6^{\text {th }}$ ed.). San Francisco, CA: Saunders.

Fan, L., Zhu, Y., \& Miao, Z. (2013). Textbook research in mathematics education: Development status and directions. ZDM, 45(5), 633-646.

Fauvel, J. (1991). Using history in mathematics education. For the Learning of Mathematics, 11(2), 3-6.

Fauvel, J. \&Van Maanen, J. (Eds.) (2000). History in mathematics education-The ICMI study. Dordrecht: Kluwer Academic.

Fried, M. N. (2001). Can mathematics education and history of mathematics coexist? Science \& Education, 10, 391-408.

Furinghetti, F. (2000). The history of mathematics as a coupling link between secondary and university teaching. International Journal of Mathematical Education in Science and Technology, 31 (1), 43-51.

Gazit, A. (2013). What do mathematics teachers and teacher trainees know about the history of mathematics? International Journal of Mathematical Education in Science and Technology, 44(4), 501-512.

Göktepe, S. \& Özdemir, A. Ş. (2013). An example of using history of mathematics in classes. European Journal of Science and Mathematics Education, 1(3), 125-136.

Gürsoy, K. (2010). A survey of prospective mathematics teachers' beliefs and attitudes towards using the history of mathematics in mathematics teaching. Unpublished master thesis, Karadeniz Technical University, Trabzon

Hagerty, G.W., Smith, S. \& Goodwin, D. (2007). The unique effects of including history in college algebra. Convergence: Where Mathematics, History and Teaching Interact, 4.

Helfgott, M. (2004). Two examples from the natural sciences and their relationship to the history and pedagogy of mathematics. Mediterranean Journal for Research in Mathematics Education, 3(1-2), 147-164.

Ho, W. K. (2008). Using history of mathematics in the teaching and learning of mathematics in Singapore. In Proceedings of $1^{\text {st }}$ RICE (pp. 1-38), Singapore: Raffles Junior.

Huntley, M. A., \& Flores, A. (2010). A history of mathematics course to develop prospective secondary mathematics teachers' knowledge for teaching. PRIMUS: Problems, Resources, and Issues in Mathematics Undergraduate Studies, 20, 603-616.

Idikut, N. (2007). The effect of benefiting from history in education of mathematics on the student's attitudes towards mathematics and their success on it. Unpublished master thesis, Yüzüncü Yıl University, Van.

Jankvist, U. T. (2009). A categorization of the "whys" and "hows" of using history in mathematics education. Educational Studies in Mathematics, 71(3), 235-261.

Jankvist, U. T. (2009a). Using history as a goal in mathematics education. Unpublished doctoral dissertation, Roskilde University, Roskilde.

Jankvist, U. T. (2010). An empirical study of using history as a 'goal'. Educational Studies in Mathematics Education, 74(1), 53-74.

Ju, M. K., Moon, J. E., \& Song, R. J. (2016). History of mathematics in Korean mathematics textbooks: Implication for using ethnomathematics in culturally diverse school. International Journal of Science and Mathematics Education, 14 (7), 1321-1338.

Katz, V. J. (1993). A history of mathematics: An introduction. NY: Harper Collins.

Kaye, E. (2008). The aims of and responses to a history of mathematics video conferencing project for schools, In Proceedings of the British for Research into learning mathematics, 28 (3).

Kleiner, I. (2001). History of the infinitely small and the infinitely large in calculus. Educational Studies in Mathematics, 48, 137-174.

213 
Leng, N. W. (2006). Effects of an ancient Chinese mathematics enrichment programme on secondary school students' achievement in mathematics. International Journal of Science and Mathematics Education, 4, 485-511.

Lim, S. Y. (2011). Effects of using history of mathematics on junior college students' attitudes and achievement, In Proceedings of AAMT-MERGA Conference 2011 Mathematics: Traditions and New Practices, 455-463.

Lingard, D. (2000). The history of mathematics: An essential component of mathematics curriculum at all levels. Australian Mathematics Teacher, 56(1), 40-44.

Liu, P. (2003). Do teachers' need to incorporate the history of mathematics in their teaching? Mathematics Teacher, 96(6), 416-421.

Liu, P., \& Niess, M. L. (2006). An exploratory study of college students' views of mathematical thinking in a historical approach calculus course. Mathematical Thinking and Learning, 8(4), 373-406.

Marshall, G. L. (2000). Using history of mathematics to improve secondary students' attitudes toward mathematics. (Unpublished doctoral dissertation), Illinois State University, Normal, IL.

McBride, C. C., \& Rollins, H. J. (1977). The effects of history of mathematics on attitudes toward mathematics of college algebra students. Journal for Research in Mathematics Education, 8(1), 5761.

McCartney, M. (2012). History of mathematics in the higher education curriculum. Maths, Stats and OR Network and HESTEM project report. http://uir.ulster.ac.uk/22942/1/HistoryofMaths.pdf

MONE, (2013). Turkish national middle school mathematics curriculum $\left(5^{\text {th }}-8^{\text {th }}\right.$ grades). Ankara: MONE

Mullis, I. V. S., Martin, M.O., Foy, P., \& Arora, A. (2012). TIMSS 2011 International results in mathematics. Chestnut Hill, MA: Boston College

Otte, M. (2007). Mathematical history, philosophy and education. Educational Studies in Mathematics, 66(2), 243-255.

Özdemir, A. Ş., Göktepe, S., \& Kepçeoğlu, i. (2012). Using mathematics history to strengthen geometric proof skills. Procedia Social and Behavioral Sciences, 46, 1177-1181.

Panasuk, R. M., \& Horton, L. B. (2012). Integrating history of mathematics into curriculum: What are the chances and constraints? International Electronic Journal of Mathematics Education, 7(1), pp.3-20.

Porter, A. C., \& Smithson, J. L. (2001). Are content standards being implemented in the classroom? A methodology and some tentative answers. In S. H. Fuhrman (Ed.), From the capitol to the classroom: Standards-based reform in the states (pp. 60-80). Chicago: University of Chicago Press.

Posner, G. J. (1995). Analyzing the curriculum ( $2^{\text {nd }}$ ed.). New York: McGraw-Hill .

Povey, H. (2014). Walking in a foreign and unknown landscape: Studying the history of mathematics in initial teacher education. Science \& Education, 23(1), 143-157.

Radford, L., Furinghetti, F., \& Katz, V. (2007). The topos of meaning or the encounter between past and present. Educational Studies in Mathematics, 66(2). pp. 107-110.

Reys, R., Reys, B., Lapan, R., Holliday, G., \& Wasman, D. (2003). Assessing the impact of" standards"based middle grades mathematics curriculum materials on student achievement. Journal for Research in Mathematics Education, 34(1), 74-95.

Smestad, B. (2000). History of mathematics in Norwegian textbooks. In Ninth International Congress on Mathematics Education, Tokyo, Japan.

Smestad, B. (2008). Teachers' conceptions of history of mathematics. Retrieved on 12, March, 2016, from http://home.hio.no/ bjorsme/HPM2008paper.pdf

Tan-Sisman, G. \& Akkaya, G. (2017). The appropriateness of the ninth grade mathematics textbooks regarding the high school mathematics curriculum [Ortaöğretim dokuzuncu sınıf matematik ders 
kitaplarının öğretim programına uygunluğu açısından incelenmesi]. Pamukkale University Journal of Education [Pamukkale Üniversitesi Eğitim Fakültesi Dergisi], 42, 1-14.

Thomaidis, Y. \& Tzanakis, C. (2009). The implementation of the history of mathematics in the new curriculum and textbooks in Greek secondary education. Dins: Working group, 15, 139-151.

Tözluyurt, E. (2008). The perceptions of senior high students regarding the lessons, in which activities chosen from history of mathematics are used on the subject of numbers learning area. (Unpublished master thesis). Gazi University, Ankara

Tyson, H. \& Woodward, A., (1989). Why students aren't learning very much from textbooks. Educational Leadership, 47(3), 14-17

Valverde, G. A., Bianchi, L. J. , Wolfe, R. G., Schmidt, W. H., \& Houang, R. T. (2002). According to the book. Using TIMSS to investigate the translation of policy in to practice through the World of textbooks. Dordrecht: Kluwer Academic Publishers.

Woodward, A., \& Elliott, D. L. (1990). Textbooks: Consensus and controversy. Chicago: National Society for the Study of Education.

Xenofontos, C., \& Papadopoulos, C. E. (2015). Opportunities of learning through the history of mathematics: the example of national textbooks in Cyprus and Greece. International Journal for Mathematics Teaching \& Learning, 1-18. Retrieved on 9 November, 2017, from http://www.cimt.plymouth.ac.uk/journal/xenofontos. pdf

Yee, L. S., \& Chapman, E. (2011). Using history to enhance student learning and attitudes in Singapore mathematics classrooms. Education Research and Perspectives, 37, 110-132.

Yenilmez, K. (2011). Prospective mathematics teachers' opinions about the history of mathematics course. Pamukkale University Journal of Education, 30, 79-90.

Acknowledgements or Notes - This is the extended version of the paper presented in the $13^{\text {th }}$ International Congress of Mathematics Education (ICME-13), Hamburg, Germany on 24-31 July, 2016. 